\title{
Kockanje mladih u Hrvatskoj - učestalost igranja i zastupljenost problematičnog kockanja'
}

\author{
Neven Ricijaš \\ Dora Dodig Hundrić \\ Sveučilište u Zagrebu, Edukacijsko-rehabilitacijski fakultet, Odsjek za poremećaje
}

u ponašanju

\author{
Aleksandra Huić \\ Sveučilište u Zagrebu, Filozofski fakultet, Odsjek za psihologiju
}

Valentina Kranželić

Sveučilište u Zagrebu, Edukacijsko-rehabilitacijski fakultet, Odsjek za poremećaje u ponašanju

Sažetak

Temeljni cilj ovog rada je istražiti zastupljenost kockanja te štetnih psihosocijalnih posljedica kockanja (tzv. problematičnog kockanja) kod hrvatskih srednjoškolaca. Dodatni ciljevi su istražiti rodne razlike te razlike u učestalosti kockanja i izraženosti problema s obzirom na razred (dob) i vrstu školskog usmjerenja. $U$ istraživanju je sudjelovalo $n=2.702$ učenika svih razreda sva tri hrvatska srednjoškolska programa (tro- i četvero-godišnje strukovne škole te gimnazije) iz 7 gradova (Zagreb, Osijek, Rijeka, Split, Vinkovci, Slavonski Brod i Koprivnica), pri čemu su podjednako zastupljeni mladići $(n=1.330$, 49.2\%) i djevojke (ž=1.372, 50.8\%), a prosječna životna dob iznosi Mdob=16.51 (SDdob=1.17).

Kako bi se ostvarili ciljevi rada, korišteni su sljedeći instrumenti: Upitnik o općim socio-demografskim podacima, Upitnik aktivnosti kockanja (Ricijaš, Dodig, Huić i Kranželić, 2011) i Kanadski upitnik kockanja adolescenata - CAGI (Tremblay, Stinchfield, Wiebe i Wynne, 2010.). Pritom je istraživanje usmjereno na formalne oblike igara na sreću, odnosno one igre koje se nude od službeno registriranih priređivača na području Republike Hrvatske.

Rezultati pokazuju kako je $72.9 \%$ srednjoškolaca barem jednom u životu kockalo/kladilo se. Najveći udio učenika ima iskustvo sportskog klađenja i igranja lutrijskih igara, pri čemu je klađenje na sportske rezultate najučestalija igra na sreću. Čak $12.9 \%$ srednjoškolaca zadovoljava kriterije za visoku razinu problema povezanih s kockanjem. Utvrđene su i značajne rodne razlike u učestalosti kockanja kao i zastupljenosti štetnih psihosocijalnih problema povezanih s kockanjem u korist mladića, dok su efekti razlika kada je riječ o vrsti škole i razredu/dobi relativno niski.

Rezultati pružaju značajne smjernice za buduća istraživanja, planiranje intervencija prema djeci i mladima, te kreiranje socijalnih politika i unaprjeđivanje zakonske regulative.

Ključne riječi: kockanje, kockanje mladih, klađenje, problematično kockanje, psihosocijalni problemi, adolescenti, srednjoškolci

1 Istraživanje je provedeno u sklopu projekta „Kockanje mladih u Hrvatskoj” koji se od 2011. godine provodi na Edukacijsko-rehabilitacijskom fakultetu u Zagrebu, uz financijsku i organizacijsku podršku Ministarstva znanosti, obrazovanja i sporta Republike Hrvatske, Agencije za odgoj i obrazovanje te Hrvatske Lutrije, d.o.o. 


\section{Uvod}

Poznato je da je upravo adolescencija razvojno razdoblje u kojem smo u povećanom riziku za uključivanje u različita rizična ponašanja. Suvremene neuroznanstvene spoznaje značajno doprinose objašnjenju etiologije takvog, za adolescenciju specifičnog, fenomena. Naime, povećana sklonost preuzimanju rizika u razdoblju prelaska iz djetinjstva u adolescenciju rezultat je promjena u dijelu mozga zaduženom za socijalno i emocionalno funkcioniranje. Takve promjene dovode do povećane potrebe za nagradom (eng. reward seeking), posebno u prisutnosti vršnjaka, što je uvjetovano prestrukturiranjem dopaminergičkog sustava (Steinberg, 2007; 2008; 2010). Stoga ne čudi da istraživanja, ali i praktično iskustvo rada s mladima, upravo u toj životnoj dobi, potvrđuju veću zastupljenost različitih rizičnih ponašanja, pa tako i kockanja (Derevensky i Gilbeau, 2015). Osim toga, današnja generacija mladih odrasta u društvu koje se u posljednja dva desetljeća pod utjecajem informatizacije i razvoja tehnologija značajno promijenilo. To se odrazilo na ponudu, ali i modalitete kockanja na tržištu igara na sreću koje je postalo sve raznovrsnije, a same aktivnosti kockanja dostupnije. Uzevši u obzir prirodu igara na sreću koja uključuje rizik i neizvjesnost ishoda, činjenicu da su (poput alkohola i droga) mladima zabranjene, te snažnu monetarnu i fiziološku nagradu koju potencijalno nose, za pretpostaviti je da lako postaju predmetom interesa, traženju uzbuđenja sklonih, adolescenata.

Istraživanja usmjerena na proučavanje ovog zanimljivog ponašajnog fenomena pokazuju da se adolescenti ne samo uključuju u različite vrste kockarskih aktivnosti, već to rade na problematičan način, koji dovodi do cijelog niza nepoželjnih posljedica. Tako rezultati studija provedenih u Sjedinjenim Američkim Državama, Kanadi i Australiji, zemljama s najduljom tradicijom istraživanja kockanja mladih, sugeriraju da između 2 i $8 \%$ mladih manifestira kompulzivne i/ili problematične obrasce kockanja (Fisher, 1993; Winters, Stinchfield i Fulkerson, 1993; Shaffer, LaBrie, Scanlan i Cummings, 1994; Shaffer i Hall, 1996; Gupta i Derevensky, 1998; Derevensky i Gupta, 2000; Jacobs, 2000; Huang i Boyer, 2007; Welte, Barnes, Tidwell i Hoffman, 2008). Nadalje, najnovijom analizom čak 44 studije o kockanju mladih (raspon dobi kretao se od 10 do 24 godine) provedenih diljem svijeta (Calado, Alexandre i Griffiths, 2016) utvrđeno je kako 0.2\% do 12.3\% mladih zadovoljava kriterije za problematično kockanje. S obzirom na geografski, društveni i kulturalni kontekst u kojem Hrvatska egzistira, u ovom ćemo se radu detaljnije usmjeriti na rezultate istraživanja u europskom prostoru. Primjerice, u Danskoj $(n=2.223)$ prošlogodišnja stopa problematičnog kockanja mladih (raspon dobi kretao se od 11 do 17 godina) iznosi 1.3\% (Kristiansen i Jensen, 2014) pri čemu je korišten mjerni instrument South Oaks Gambling Screen (Lesieur i Blume, 1987), verzija revidirana za adolescente SOGS-RA (Winters, Stinchfield i Fulkerson, 1993). U Finskoj je istim mjernim instrumentom na uzorku od čak $n=5.000$ mladih utvrđen identičan udio problematičnih kockara (Ilkas $\mathrm{i}$ Aho, 2006, prema Calado, Alexandre i Griffiths, 2016), dok je modificiranim instrumentom proizašlim iz DSM-IV kriterija (1996) za patološko kockanje (DSM-IV-MR-J, Fisher, 2000) prepoznato 7.9\% mladih koji su u riziku ili su već razvili probleme povezane s kockanjem (Castren, Grainger, Lahti, Alho i Salonen, 2015). Na Islandu ( $n=750)$, SOGS-RA kriterije problematičnog kockanja zadovoljava 2.7\% mladih (Olason, Sigurdardottir i Smari, 2006). U Norveškoj je provedeno nekoliko istraživanja, te su korištenjem različitih instrumenata procjene utvrđeni i različiti udjeli mladih s problemima povezanim s kockanjem. Tako su Johansson i Götestam (2003) na uzroku od n=3.237 djece i mladih, primjenom DSM-IV instrumenta, identificirali 1.76\% patoloških i 3.46\% problematičnih kockara. 
Rossow i Molde (2006) koristili su SOGS-RA i utvrdili udio od 2.5\% mladih problematičnih kockara, dok je u istraživanju Hanssa i suradnika (2014) tek $0.2 \%$ mladih manifestiralo ozbiljnije probleme povezane s kockanjem, prema kriterijima instrumenta Problem Gambling Severity Index - PGSI, autora Ferrisa i Wynnea (2001). Rezultati estonskog nacionalnog istraživanja $(n=2.005)$ pokazuju da je $75 \%$ ispitanika imalo iskustvo kockanja, te da njih 3.4\% zadovoljava SOGS kriterije za patološko kockanje. lako se raspon dobi sudionika kretao od 15 do 74 godine, autori zaključuju da su upravo mladi u većem riziku za razvoj problema, te da u većoj mjeri čine skupinu onih s razvijenim problemima (Laansso, 2006, prema Volberg, Gupta, Griffiths, Olason i Delfabbro, 2010). U Litvi su, na uzorku od $n=835$ mladih od 9 do 16 godina, korištena dva instrumenta procjene: SOGS-RA prepoznao je 5.2\%, a DSM-IV-MR-J 4.2\% mladih problematičnih kockara (Skokauskas, 2009). Što se tiče Njemačke, Hurrelman, Schmidt i Kahnert (2003, prema Volberg i sur., 2010) na uzorku od $n=5.000$ mladih od 13 do 19 godina utvrdili su da je njih 62\% kockalo u protekloj godini, a 3\% zadovoljava (DSM-IV-MR-J) kriterije problematičnog kockanja, pri čemu su mladići u značajno većem riziku. U Švicarskoj je utvrđen udio od $4.3 \%$ mladih u riziku i 1.3\% onih s razvijenim problemima povezanim s kockanjem (Tozzi, Akre, Fleury-Schubert i Suris, 2013). Nešto viši udjeli mladih problematičnih kockara zabilježeni su u Španjolskoj gdje su Becoña, Míguez i Vázquez (2001) identificirali 5.6\% mladih s razvijenim problemima (SOGS-RA). Velika Britanija slijedi s približnim rezultatima. Tako Griffiths i Wood (2007), na reprezentativnom uzorku, izvještavaju o 3.5\% problematičnih kockara. U Rumunjskoj je u dva istraživanja primijenjen instrument GA-20 (eng. Gamblers Anonymous Twenty Questions) te je utvrđeno da 6.8\% (Lupu, Onaca i Lupu, 2002), odnosno 3.48\% (Lupu i Todirita, 2013) mladih zadovoljava kriterije problematičnog kockanja. U Italiji istraživanja potvrđuju značajne udjele mladih s problemima povezanim s kockanjem: Villella i suradnici (2011) u uzorku od $n=2.853$ mladih od 13 do 20 godina prepoznali su 7\% onih koji već imaju razvijene probleme, dok taj udio u istraživanju Colasantea i suradnika (2014) u uzorku od $n=5.930$ mladih, iznosi 5.9\% (u oba je istraživanja kao instrument procjene korišten SOGS-RA). U češkom nacionalnom prevalencijskom istraživanju, u skupini mladih između 15 i 24 godine utvrđeno je da je njih $7.4 \%$ u riziku da razvije probleme povezane s kockanjem (korištena je Lie/Bet skala), dok je taj udio u subuzorcima starijih odraslih osoba znatno niži i kreće se od 3.3\% do 5.7\%, ovisno o životnoj dobi (Mravčík i sur., 2014). Kada je riječ o zemljama koje su nama geografski i kontekstualno bliže i sličnije, za Srbiju su nam dostupni podaci prikupljeni kroz "Nacionalno istraživanje o stilovima života stanovništva Srbije"2 prema kojima je 3.7\% stanovnika u riziku za razvoj problema. Kada je riječ o maloljetnicima, o značajnoj zastupljenosti problema možemo posredno zaključiti na temelju rezultata ESPAD studije provedene 2011. godine $(n=6.084)$ prema kojima $3.1 \%$ srpskih učenika kocka na način da im ono potencijalno narušava psihosocijalno funkcioniranje (Molinaro i sur., 2014). U Bosni i Hercegovini provedeno je istraživanje s metodologoijom istovjetnom onoj iz kojeg su proizašli i rezultati prikazani u ovom radu, te je u uzorku od $n=1.036$ srednjoškolaca iz Sarajeva i Tuzle utvrđeno da je njih 69.3\% imalo iskustvo kockanja tijekom života, te da su najzastupljenije igre jednokratne srećke (41.9\%), sportska kladionica Lutrije BiH (36.1\%), sportske kladionice (34\%), te TV Bingo (29.5\%). Nadalje, njih čak $8.3 \%$, prema kriterijima Kanadskog upitnika kockanja adolescenata - CAGI (Tremblay, Stinchfield, Wiebe i Wynne, 2010) ima ozbiljne štetne psihosocijalne posljedice povezane s kockanjem (Bijedić, Kuralić-Čišić, Kovačević i Vardo, 2015).

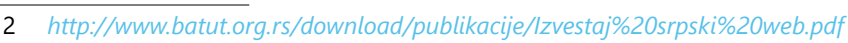


Iz prikazanih je rezultata vidljivo da se zastupljenost problematičnog kockanja mladih razlikuje od države do države. Štoviše, nerijetko i unutar jedne države pronalazimo značajno različite pokazatelje. Jedan od razloga je nedvojbeno metodologija istraživanja, odnosno korištenje različitih mjernih instrumenata i metoda uzorkovanja, što nam onemogućava neposrednu usporedbu. No, ne smijemo zanemariti niti vrlo značajan utjecaj okolinskih čimbenika, prije svega dostupnosti i pristupačnosti kockanja, zakonske regulative, ali i oglašavanja samih igara. I suvremeni teorijski modeli problematičnog kockanja mladih naglašavaju važnost dostupnosti, polazeći od pretpostavke kako, da bismo razvili problem povezan s prekomjernim sudjelovanjem u igrama na sreću, same igre prvo trebaju biti dostupne (Blaszczynski i Nower, 2002; Nower i Blaszczynski, 2004). U tom smislu, za pretpostaviti je da zemlje s povećanom dostupnošću imaju i više stope problematičnih kockara. Naravno, ta povezanost nije linearna i uzročno-posljedična, te u obzir treba uzeti i druge čimbenike, no doprinos tih varijabli nije zanemariv što potvrđuju i inozemna istraživanja (Becona i sur., 1995, prema Raylu i Oei, 2002; Productivity Commission, 1999; Campell i Lester, 1999; Ladouceur, Jacques, Ferland i Giroux, 1999). Ovo je posebno relevantno prilikom bavljenja problemom kockanja u Republici Hrvatskoj s obzirom da se naša zemlja odlučila za liberalan pristup u organizaciji igara na sreću što se značajno odrazilo na porast dostupnosti igara na sreću, posebno sportskog klađenja i igara na automatima. Konkretno, prema podacima Državnog zavoda za statistiku (2010) ${ }^{3}$, devedesetih je godina u Hrvatskoj bilo oko 350 prodajnih mjesta registriranih za priređivanje/prodaju igara na sreću, da bi 2009. godine ta brojka porasla na više od 1600. Štoviše, noviji pokazatelji sugeriraju da se uzlazni trend kontinuirano nastavlja, te tako danas u Republici Hrvatskoj djeluje 15 kasina, 234 automat klubova (s ukupno čak 7.753 automata), te 4.099 uplatnih mjesta za priređivanje igara klađenja ${ }^{4}$. Kod potonje igre na sreću primjećujemo i najznačajniji rast, te je broj uplatnih mjesta u petogodišnjem razdoblju (između 2010. i 2015. godine) porastao za čak 1.000. Nadalje, ne smijemo zanemariti niti činjenicu da su se razvojem tehnologija proširili modaliteti i mogućnosti sudjelovanja u igrama na sreću, te je danas u gotovo svim igrama na sreću moguće sudjelovati putem interneta (od kuće), a i kladiti se preko samoposlužnih terminala (tzv. kladomata) koji su najčešće smješteni u ugostiteljskim objektima (kafićima). Uslijed takvih okolnosti, realna dostupnost igara na sreću nedvojbeno je i veća od one koju možemo iščitati iz objektivnih pokazatelja.

Što se tiče same zakonske regulative, Zakonom o igrama na sreću iz (NN 87/09, 35/13, 158/13, 41/14, 143/14; u daljnjem tekstu Zakon) regulirano je tržište igara na sreću, te su upravo donošenjem ovog Zakona, koji je stupio na snagu 2010. godine, sve igre zabranjene mlađima od 18 godina. No, kao što ćemo vidjeti u nastavku ovog rada, usprkos toj regulativi, maloljetnici uspijevaju pristupiti aktivnostima kockanja. Tome svakako doprinosi prethodno opisana dostupnost igara na sreću, no kada je riječ o djeci i mladima, ne smijemo zanemariti niti oglašavanje igara na sreću gdje je također vidljiv liberalan pristup kojem se priklonila naša zemlja. Naime, dok kod oglašavanja alkohola i duhanskih proizvoda postoje značajne restrikcije (Zakon o elektroničkim medijima, 2009), zakonodavac je oglašavanje igara na sreću zabranio samo u medijskim sadržajima namijenjenim ciljano djeci i mladima (Zakon o igrama na sreću, NN 87/09, 35/13, 158/13, 41/14, 143/14). Ovakav je pristup u suprotnosti s preporukama vodećih stručnjaka u području koji, temeljem dugogodišnjeg iskustva i znanstvenih istraživanja, za oglašavanje igara na sreću predlažu ista pravila koja vrijede za alkohol i cigarete (Griffiths, 2005).

3 Podaci dobiveni od Državnog zavoda za statistiku za potrebe projekta „Kockanje mladih u Hrvatskoj”

4 Dopis Ministarstva financija s predmetom „Priređivanje igara na sreću u Republici Hrvatskoj - podaci“ dostavljen voditelju projekta „Kockanje mladih u Hrvatskoj”, doc.dr.sc. Nevenu Ricijašu, 16. lipnja 2016. 
Iz prethodnog je teksta jasno da inozemni pokazatelji kontinuirano potvrđuju značajnu zastupljenost problematuičnog kockanja mladih. Uz to, u našoj zemlji svjedočimo liberalnom pristupu igrama na sreću koje u svoje središte pozornosti stavlja ekonomsku dobit i odgovornost prebacuje na slobodnu volju građana. Ovakav pristup ima značajnih nedostataka posebno kada je riječ o mladima i odgovornosti društva da im osigura povoljne uvjete za odrastanje i ostvarivanje povoljnih razvojnih ishoda. Ti uvjeti u Hrvatskoj nisu zadovoljeni kada je riječ o zaštiti mladih od ove rizične aktivnosti, a u prilog tome govore i rezultati istraživanja na našim prostorima provedenih unazad nekoliko godina. U sklopu projekta „Zlouporaba sredstava ovisnosti u općoj populaciji Republike Hrvatske" (Glavak Tkalić i Miletić, 2012), utvrđeno je da je 66.5\% "mlađih odraslih" osoba (15 do 24 godina) barem jednom sudjelovalo u igrama na sreću, te da 3.2\% njih smatra da je nekad u životu imalo problema povezanih s kockanjem (u odnosu na 1.5\% u skupini odraslih osoba). Istraživanjem provedenim u Virovitici (Koić i Medved, 2009) dobiven je podatak da 38.5\% mladića, učenika srednjih škola, sudjeluje u igrama na sreću dok taj udio u ukupnom uzorku učenika i učenica s područja Bjelovarsko-bilogorske županije iznosi 44.9\% (Puharić, Kudumija Sljepčević, Badrov i Petričević, 2016). Oko 75\% srednjoškolaca iz Zagreba navodi da su barem jednom u životu kockali, a u istom istraživanju njih između 8 i 12\% (ovisno o korištenom instrumentu) pokazivalo je rizične obrasce kockanja (Dodig i Ricijaš, 2011).

Međutim, unatoč podacima iz pojedinačnih istraživanja, ono što svakako nedostaje jest sustavan pregled temeljnih pokazatelja o kockanju hrvatskih srednjoškalaca, kao što su zastupljenost različitih igara na sreću, učestalost igranja te stopa problematičnog kockanja, što je glavni cilj ovog rada. Unatoč deskriptivnoj prirodi ovog cilja, on direktno pridonosi budućim prevencijskim i svim drugim intervencijskim strategijama, a i omogućava provjeru ranije navedene teze da je veća dostupnost i pristupačnost mjesta za priređivanje igara na sreću povezana s većom učestalosti i rizičnosti kockanja mladih. S obzirom na, za Hrvatsku karakterističnu visoku dostupnost i pristupačnost priređivačkih mjesta, očekivali smo da će hrvatski srednjoškolci kockati više te problematičnije od srednjoškolaca iz drugih europskih i inih zemalja.

Također, inozemna istraživanja pokazuju kako su već neka osnovna socio-demografska obilježja adolescenata rizičan čimbenik za kockanje srednjoškolaca, stoga je dodatni cilj rada provjeriti rodne i dobne razlike u zastupljenosti i rizičnosti kockanja u specifičnom hrvatskom kontekstu, kao i razlike s obzirom na vrstu srednjoškolskog programa.

Naime, prema rezultatima stranih istraživanja, mladići uglavnom češće kockaju od djevojaka i to mahom one vrste igara koje su opasnije za razvoj ozbiljnijih problema s kockanjem, pa ne čudi da muški rod predstavlja rizičan čimbenik za razvoj problematičnog kockanja (Derevensky i Gilbeau, 2015; Desai, Maciejewski, Pantalon i Potenza, 2005; Donati, Chiesi i Primi, 2013; Welte, Barnes, Tidwell i Hoffman, 2009). Stoga smo očekivali da će mladići i u našem uzorku kockati više nego djevojke, te izvještavati o ozbiljnijim posljedicama zbog svojeg kockanja nego djevojke.

Osim toga, istraživanjem smo željeli ispitati i eventualne dobne razlike u učestalosti kockanja i psihosocijalnim problemima koji se javljaju kao posljedica kockanja. Ove razlike posebno je važno ispitati s obzirom na nalaze istraživanja koja pokazuju kako je rano uključivanje u igre na sreću povezano s većom vjerojatnosti kasnijeg problematičnog kockanja, kao i većim rizikom za razvoj ovisnosti o kocki u odrasloj dobi (Carbonneau, Vitaro, Brendgen i Tremblay, 2015; Delfabbro, King 
i Griffiths, 2014; Rahman i sur., 2012). Međutim, niti u domaćim, niti u stranim istraživanjima, ne mogu se pronaći sustavni podaci o dobnim razlikama u kockanju adolescenata. S obzirom da je u Hrvatskoj kockanje zakonski zabranjeno osobama mlađima od 18 godina, moguće je pretpostaviti da će mjesta na kojima se priređuju igre na sreću biti ipak manje pristupačna mlađim adolescentima (npr. srednjoškolcima koji tek pohađaju prvi razred), nego srednjoškolcima završnih razreda. Također, s obzirom na to da je potrebno određeno vrijeme da se kockanjem razviju psihosocijalni problemi, očekivali smo da će učenici viših razreda u većoj mjeri činiti skupinu problematičnih kockara. No, s obzirom na nedostatak istraživanja na ovu temu, teško je postaviti neke direktivnije hipoteze.

Hrvatska istraživanja koja se bave drugim vrstama rizičnog ponašanja konzistentno pokazuju kako se učenici koji pohađaju strukovne srednjoškolske programe u većoj mjeri uključuju u rizične aktivnosti od učenika koji pohađaju gimnazijski program (Ajduković, Ručević i Šincek, 2009; Kuzman, 2003). Istovremeno, kao što i strana i hrvatska istraživanja pokazuju, kockanje adolescenata često se javlja paralelno s uključivanjem i u druga rizična i delikventna ponašanja (Ricijaš, Dodig Hundrić i Kranželić, 2015; Welte i sur., 2009). Stoga smo očekivali da ćemo i u ovom istraživanju dobiti sličan trend, te da će srednjoškolci iz strukovnih škola izvještavati o većoj uključenosti u kockarske aktivnosti, kao i o rizičnijem kockanju u odnosu na srednjoškolce iz gimnazija.

\section{Metodologija}

\subsection{Uzorak sudionika}

Istraživanje je provedeno s prigodnim uzorkom od $n=2.702$ srednjoškolca iz sedam hrvatskih gradova ( $m=1.330,49.2 \% ; \check{z}=1.372,50.8 \%)$. U istraživanju su sudjelovali učenici svih vrsta srednjoškolskih usmjerenja, od prvog do završnog razreda. U tablici 1 prikazana je distribucija sudionika $s$ obzirom na grad, vrstu škole i razred koji pohađaju. Raspon dobi sudionika kreće se od 14. do 21. godine života, pri čemu je prosječna dob Mdob=16.51 (SDdob=1.17).

U većim gradovima, odnosno regionalnim središtima (Zagreb, Split, Rijeka i Osijek) izabrane su dvije škole unutar svakog usmjerenja (gimnazijski program, strukovno četverogodišnje obrazovanje, strukovno trogodišnje obrazovanje), te je istraživanje provedeno u jednom razredu svake generacije (od prvog do završnog) na način da je razred biran po slučaju. U manjim gradovima (Slavonski Brod, Vinkovci i Koprivnica) izabrana je jedna škola po usmjerenju, a razredi su birani istim principom.

Tablica 1 Opis uzorka prema osnovnim sociodemografskim obilježjima $(n=2.702)$

\begin{tabular}{|c|c|c|c|c|c|c|c|}
\hline $\begin{array}{c}\text { Grad } \\
\%\end{array}$ & $\begin{array}{c}\text { Zagreb } \\
16.5 \%\end{array}$ & $\begin{array}{l}\text { Split } \\
19.9 \%)\end{array}$ & $\begin{array}{l}\text { Rijeka } \\
16.8 \%\end{array}$ & $\begin{array}{l}\text { Osijek } \\
18.8 \%\end{array}$ & $\begin{array}{l}\text { SI. Brod } \\
9.8 \%\end{array}$ & $\begin{array}{l}\text { Vinkovci } \\
8.9 \%\end{array}$ & $\begin{array}{c}\text { Koprivnica } \\
9.3 \%\end{array}$ \\
\hline $\begin{array}{c}\text { Vrsta škole } \\
\%\end{array}$ & \multicolumn{2}{|c|}{$\begin{array}{c}\text { Strukovna trogodišnja } \\
23.4 \%\end{array}$} & \multicolumn{3}{|c|}{$\begin{array}{c}\text { Strukovna četverogodišnja } \\
37.6 \%\end{array}$} & \multicolumn{2}{|c|}{$\begin{array}{l}\text { Gimnazija } \\
39.0 \%\end{array}$} \\
\hline $\begin{array}{c}\text { Razred } \\
\%\end{array}$ & \multicolumn{2}{|c|}{$\begin{array}{l}\text { 1. Razred } \\
28.4 \%\end{array}$} & $\begin{array}{l}\text { 2. Razred } \\
26.4 \%\end{array}$ & & $\begin{array}{l}\text { 3. Razred } \\
26.6 \%\end{array}$ & \multicolumn{2}{|c|}{$\begin{array}{l}\text { 4. Razred } \\
16.6 \%\end{array}$} \\
\hline
\end{tabular}

Iz prikazanih je podataka vidljivo kako je broj učenika gimnazija (39.0\%) i strukovnih četverogodišnjih škola (37.6\%) podjednak, dok je broj polaznika trogodišnjeg strukovnog programa očekivano manji i iznosi $23.4 \%$. Slično je i s razredom na način da su prva tri razreda podjednako 
zastupljena, dok je, zbog nepostojanja četvrtog razreda u strukovnim trogodišnjim programima, udio učenika koji pohađaju četvrti razred nešto manji.

Testiranjem rodnih razlika u odnosu na pojedine demografske kriterije utvrđeno je kako postoji mala razlika s obzirom na dob, na način da su mladići nešto stariji od djevojaka (Mdob_m=16.58; Mdob_ž $=16.45 ; t=2.807 ; p<.010)$. S obzirom na vrstu škole, djevojke $u$ nešto većoj mjeri pohađaju gimnazijski program $\left(\chi^{2}=123.59 ; p<.001\right)$, dok razlike $s$ obzirom na razred ne postoje $\left(\chi^{2}=8.91\right.$; $p>$.050).

\subsection{Instrumentarij}

Prvo smo Upitnikom o općim socio-demografskim podacima ispitali ključne socio-demografske podatke kao što su spol, dob, vrsta škole i razred sudionika istraživanja.

Zatim je korišten Upitnik aktivnosti kockanja (Ricijaš, Dodig, Huić i Kranželić, 2011) koji sadrži pitanja o učestalosti igranja šest ključnih $i$, u našem društvu, najdostupnijih formalnih igara na sreću (sportsko klađenje, loto, jednokratne srećke, igre na automatima, rulet i klađenje na virtualne utrke). Formalni aspekt igara na sreću odnosi se na činjenicu da su one ponuđene od službenih priređivača koji imaju licencu za priređivanje igara na sreću na području Republike Hrvatske, ali su istovremeno zakonom maloljetnicima zabranjene. On-line igranje nije bilo posebno ispitivano budući da su sve igre na sreću u Hrvatskoj dostupne putem interneta, te ono samo predstavlja modalitet igranja, a ne vrstu igre. Neformalni oblici kockanja (npr. klađenje između prijatelja ili kartanje za novac) nije uvršteno u ovaj rad, s obzirom da je interes ovog rada povezati formalan društveni aspekt s prevalencijom kockanja i razvojem štetnih psihosocijalnih posljedica kod mladih.

Zadatak sudionika bio je za svaku igru označiti jesu li je ikada u životu igrali (ne/da) te, ukoliko jesu, koliko često to čine. Raspon bodovanja je od 0 do 5 , pri čemu bojevi imaju sljedeća značenja: $0=$ nikada, $1=$ jednom godišnje ili manje od toga, $2=$ otprilike jednom mjesečno, $3=$ otprilike jednom tjedno, 4=nekoliko puta tjedno, $5=$ svakodnevno.

Kanadski upitnik kockanja adolescenata - CAGI (Tremblay, Stinchfield, Wiebe i Wynne, 2010) korišten je za mjerenje intenziteta štetnih psihosocijalnih posljedica kockanja srednjoškolaca 5 . Točnije, korištena je GPSS subskala (eng. general problem severity subscale) koja s 9 tvrdnji mjeri opću razinu štetnih psihosocijalnih posljedica, a temeljem ukupnog rezultata na ovoj subskali, adolescente je moguće kategorizirati u tri skupine:

1. nepostojanje problema povezanih s kockanjem (tzv. zeleno svjetlo) - 0 i 1 bod,

2. niska do srednja ozbiljnost problema povezanih s kockanjem (tzv. žuto svjetlo) -2 do 5 bodova,

3. visoka ozbiljnost problema povezanih s kockanjem (tzv. crveno svjetlo) - 6 bodova i više.

Zadatak sudionika je odgovoriti koliko često su se ponašali/osjećali na određeni način, a sadržaj čestica pokriva cijeli spektar psihosocijalnih posljedica, od psiholoških i gubitka kontrole, preko socijalnih do onih financijskih. Primjer čestica je „Koliko često si se osjećao loše zbog načina

5 Više o cijelom instrumentu i njegovim metrijskim karakteristikama vidjeti Dodig (2013) 
na koji kockaš/kladiš se, ili zbog onoga što se događa dok kockaš/kladiš se?" ( $0=$ nikada, $1=$ ponekad, 2 =većinu vremena, 3 =gotovo uvijek) ili „Koliko često si se vraćao drugi dan kako bi pokušao vratiti novac izgubljen kockanjem/klađenjem?" ( $0=$ nikada, $1=$ jedan do tri puta, $2=$ četiri do šest puta, $3=$ sedam ili više puta). Skala pokazuje zadovoljavajuće metrijske karakteristike tipa unutarnje konzistencije na način da Cronbachova alfa na cijelom uzorku iznosi $\alpha=.849$, a prema rodu $\alpha m=.834 ; \alpha z ̌=.788$.

Za primjenu instrumenta u ovom istraživanju traženo je i dobiveno pismeno dopuštenje autora. S obzirom na to da je instrument originalno na engleskom jeziku, napravljen je postupak dvostrukog prijevoda (eng. back translation) na način da je prvo napravljen prijevod s engleskog jezika na hrvatski, a potom je nezavisni prevoditelj preveo s hrvatskog na engleski. Prevedena engleska verzija poslana je autorima na provjeru, nakon čega je dobivena dozvola za primjenu.

\subsection{Postupak provedbe istraživanja i poštivanje etičkih načela}

Istraživanje je provedeno u razdoblju od 2011. do 2013. godine na uzorku srednjoškolaca iz 7 hrvatskih gradova (Zagreb, Osijek, Rijeka, Split, Koprivnica, Vinkovci i Slavonski Brod). Učenici su upitnik ispunjavali grupno, u vlastitom razredu. Istraživanje je u svim srednjim školama proveo tim stručnjaka s Edukacijsko-rehabilitacijskog fakulteta i Filozofskog fakulteta Sveučilišta u Zagrebu, uz pomoć studenata završne godine diplomskog studija socijalne pedagogije.

Ispunjavanje upitnika trajalo je jedan školski sat, odnosno 45 minuta, a provedeno je po principu papir-olovka. Pritom su svi sudionici bili usmeno informirani o osnovnom cilju istraživanja, njihovo sudjelovanje je bilo anonimno i dobrovoljno, te su mogli odustati u bilo kojem trenutku ispunjavanja upitnika. Ispitivanje je provedeno u skladu s Etičkim kodeksom istraživanja s djecom (Ajduković i Kolesarić, 2003), a za provedbu istraživanja i cjelokupni projekt dobivena je suglasnost Etičkog povjerenstva Edukacijsko-rehabilitacijskog fakulteta Sveučilišta u Zagrebu.

\subsection{Metode obrade podataka}

S ciljem stjecanja uvida u prevalenciju kockanja i zastupljenosti štetnih psihosocijalnih posljedica korištene su metode deskriptivne statistike (frekvencije odgovora, mjere srednjih vrijednosti), dok su za rangiranje učestalosti igranja pojedinih igara korišteni Friedmanov test (neparametrijski ekvivalent zavisnoj analizi varijance) i Wilcoxonov test ranga. Razlike u učestalosti kockanja s obzirom na postavljene nezavisne varijable (rod, razred, vrsta škole) testirane su Mann-Whitneyevim U-testom ili Kruskal-Wallisovim testom (neparametrijske metode), te $\chi^{2}$-kvadrat testom.

\section{Rezultati istraživanja}

Pitanjem jesu li ikada u životu igrali jednu od šest formalnih igara na sreću (tzv. životna prevalencija) istražili smo koliko srednjoškolaca je barem jedanput u životu kockalo (slika 1). Iz rezultata uočavamo kako je gotovo $3 / 4$ srednjoškolaca, točnije njih $73 \%$, barem jedanput u životu sudjelovalo u nekoj formalnoj igri na sreću. Životnu prevalenciju kockanja također smo testirali i kod onih srednjoškolaca koji su bili maloljetni u vrijeme provedbe istraživanja ( 17 godina života), budući da punoljetni srednjoškolci imaju zakonsko pravo pristupiti igrama na sreću. Rezultati pokazuju kako činjenica da su maloljetni, hrvatske srednjoškolce ne sprječava u pristupu igrama na 
sreću. Dapače, u subuzorku maloljetnih srednjoškolaca, rezultati pokazuju kako svega $19.7 \%$ njih nije nikada igralo igre na sreću.

Kockali barem jedanput u životu?

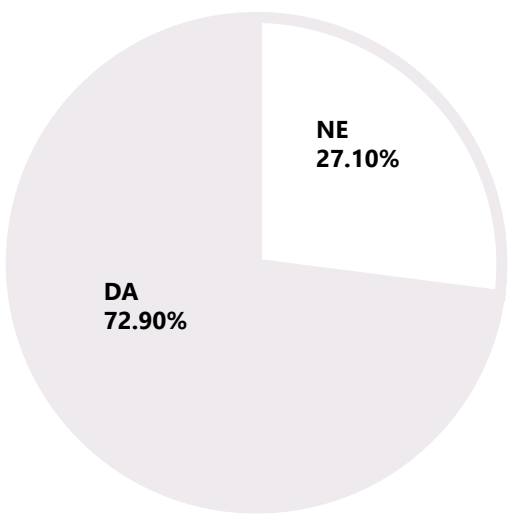

Slika 1 Grafički prikaz životne prevalencije kockanja $(n=2.702)$

Na Slici 2 prikazani su rezultati $\chi^{2}$-kvadrat testa kojim smo provjerili rodne razlike u životnoj prevalenciji, a iz grafičkog prikaza je vidljivo kako je veći broj djevojaka barem jednom u životu kockalo (80\% naspram $\left.66 \% ; \chi^{2}=60.305 ; p<.001\right)$. Pritom treba imati na umu da nam ovaj podatak govori samo o tome je li netko barem jednom u životu sudjelovao u nekoj igri na sreću (primjerice, netko je mogao jednom sudjelovati u nekoj lutrijskoj igri), a ne o učestalosti kockanja koja je od posebnog značaja u objašnjenju problematičnog kockanja.

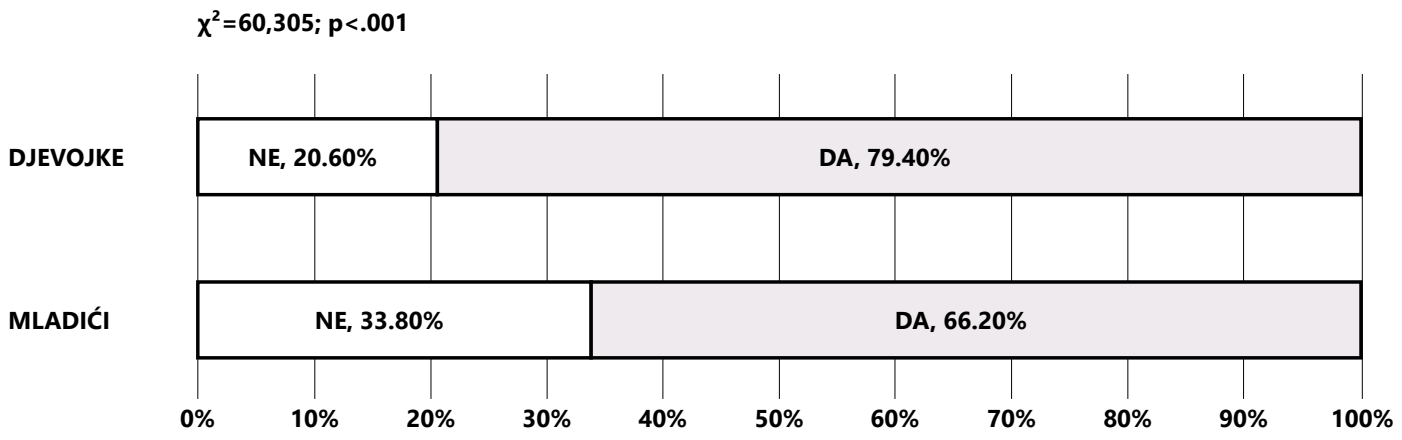

Slika 2 Grafički prikaz rodnih razlika u životnoj prevalenciji kockanja - $\chi^{2}$-test $(n=2.702)$

Potom smo srednjoškolce pitali o životnoj prevalenciji igranja različitih igara na sreću, te su rezultati prikazani u tablici 2. Iz prikazanog uočavamo kako je najveći broj srednjoškolaca imao iskustvo sportskog klađenja (oko 40\% srednjoškolaca barem jednom u životu kladilo se na sportske rezultate), a zatim igranja lutrijskih igara kao što su jednokratne srećke i loto listići. Njih oko $20 \%$ imalo je iskustvo igranja na automatima i klađenja na virtualne utrke, a 10\% u životu je barem jednom igralo elektronski rulet. 
Tablica 2 Deskriptivni prikaz frekvencija odgovora o igranju pojedinih igara na sreću (životna prevalencija); $n=2,702$

\begin{tabular}{|c|c|c|c|c|c|c|}
\cline { 2 - 7 } \multicolumn{1}{c|}{} & $\begin{array}{c}\text { Sportsko } \\
\text { klađenje }\end{array}$ & Loto & Jednokratne srećke & Igre na automatima & Elektronski rulet & $\begin{array}{c}\text { Klađenje na virtualne } \\
\text { utrke }\end{array}$ \\
\hline NE & $59.3 \%$ & $66.3 \%$ & $53.2 \%$ & $78.8 \%$ & $90.5 \%$ & $79.4 \%$ \\
\hline DA & $40.7 \%$ & $33.7 \%$ & $46.8 \%$ & $21.2 \%$ & $9.5 \%$ & $20.6 \%$ \\
\hline
\end{tabular}

No, uz sam podatak o životnoj prevalenciji, posebno nam je važan podatak o učestalosti. Točnije, zanimalo nas je i u kojoj mjeri srednjoškolci u našem uzorku sudjeluju u kockarskim aktivnostima tj. koliko njih kocka povremeno, a koliko redovito. Na temelju kriterija koje predlažu Felsher, Derevensky i Gupta (2004), redovito kockanje definirali smo kao učestalost od jednom tjedno ili češće od toga, odnosno ta kategorija, od ponuđenih odgovora u Upitniku aktivnosti kockanja, obuhvaća odgovore "1x tjedno", "nekoliko puta tjedno" $\mathrm{i}$ "svakodnevno". U tom smislu, a sumirajući rezultate prikazane u tablici 3, uočavamo kako je sportsko klađenje najučestaliji oblik kockanja, te kako učestalost igranja te igre na sreću značajno odudara od učestalosti igranja drugih igara. Oko $20 \%$ hrvatskih srednjoškolaca redovito se kladi na sportske rezultate, a potom slijede igre na automatima i klađenje na virtualne utrke (oko 7\%). Lutrijske igre i elektronski rulet najmanje su zastupljeni u kategoriji redovitog igranja s oko $3 \%$.

Tablica 3 Deksriptivni prikaz učestalosti kockanja srednjoškolaca - frekvencije odgovora (\%) $(n=2.702)$

\begin{tabular}{|l|c|c|c|c|c|c|}
\hline \multicolumn{1}{|c|}{ Vrsta igre } & Nikada & $\begin{array}{c}\text { 1x godišnje } \\
\text { ili manje od } \\
\text { toga }\end{array}$ & 1x mjesečno & 1x tjedno & $\begin{array}{c}\text { Nekoliko puta } \\
\text { tjedno }\end{array}$ & $\begin{array}{c}\text { Svakodnevno } \\
\text { Sportsko klađenje }\end{array}$ \\
\hline Loto & 59.3 & 11.1 & 10.2 & $\mathbf{8 . 3}$ & $\mathbf{6 . 6}$ & $\mathbf{4 . 5}$ \\
\hline Jednokratne srećke & 66.3 & 22.6 & 7.5 & $\mathbf{2 . 8}$ & $\mathbf{0 . 5}$ & $\mathbf{0 . 3}$ \\
\hline Igre na automatima & 75.2 & 35.3 & 8.4 & $\mathbf{2 . 7}$ & $\mathbf{0 . 4}$ & $\mathbf{0 . 0}$ \\
\hline Elektronski rulet & 90.5 & 9.8 & 7.4 & $\mathbf{3 . 6}$ & $\mathbf{2 . 2}$ & $\mathbf{1 . 3}$ \\
\hline $\begin{array}{l}\text { Klađenje na virtualne } \\
\text { utrke }\end{array}$ & 79.4 & 7.6 & 2.6 & $\mathbf{0 . 9}$ & $\mathbf{0 . 6}$ \\
\hline
\end{tabular}

Promatrajući ukupnu učestalost kockanja, zanimalo nas je koje se igre najčešće, a koje najrjeđe igraju. U tablici 4 prikazane su prosječne vrijednosti za učestalost igranja svake igre. Kako bismo točno rangirali igranje pojedinačne igre prvo smo izračunali Friedmanov test (neparametrijski ekvivalent zavisnoj analizi varijance) koji je pokazao da se učestalost igranja pojedinačnih igara značajno međuosbno razlikuje $\left(\chi^{2}=1440.758, p<.001\right)$. Kako bismo utvrdili točno između kojih igara postoje značajne razlike proveli smo seriju Wilcoxonovih testova (neparametrijski ekvivalent t-testa za zavisne uzorke) koji su pokazali značajne razlike između svih igara osim lota, igre na automatima i klađenja na virtualne utrke (vidi tablicu 4). Iz rezultata je vidljivo da je sportsko klađenje prosječno najučestaliji oblik kockanja, a nakon njega slijedi igranje jednokratnih srećki. Igranje lota, automata i klađenje na virtualne utrke dijele treće mjesto, dok je igranje elektronskog ruleta najrjeđe. 
Neven Ricijaš, Dora Dodig Hundrić, Aleksandra Huić, Valentina Kranželić: Kockanje mladih u Hrvatskoj...

Tablica 4 Rangiranje učestalosti kockanja svih igara- $t$-test za zavisne uzorke - svi $(n=2.702)$

\begin{tabular}{|c|c|c|c|c|}
\hline Rang & Vrsta igre & M & SD & Pojedinačni Wilcoxonovi testovi ranga \\
\hline 1 & Sportko klađenje & 1.05 & 1.530 & $\begin{array}{c}Z_{\text {SK-JS }}=-13.694^{* *} ; Z_{\text {SK-LO }}=-17.843^{* *} ; Z_{\text {SK-AU }}=-19.782^{* *} ; Z_{\text {SK }} \\
v U=-21.537^{* *} ; z_{\text {SK-ER }}=-26.565^{* *}\end{array}$ \\
\hline 2 & Jednokratne srećke & 0.62 & 0.790 & $\begin{array}{c}Z_{J S-L O}=-8.257^{* *} ; Z_{J s-A U}=-6.194^{* *} ; Z_{J s-V u}=-8.333^{* *} \\
Z_{J S-R R}=-21.599^{* *}\end{array}$ \\
\hline \multirow{3}{*}{3} & Loto & 0.49 & 0.828 & $Z_{\text {LO-AU }}=-0.372 ; Z_{\text {LO- }-v U}=2.289 ; Z_{\text {LO-ER }}=-15.187^{\star *}$ \\
\hline & Igre na automatima & 0.50 & 1.061 & $Z_{A U-v U}=1.727 ; Z_{A U-E R}=-16.127^{\star *}$ \\
\hline & $\begin{array}{l}\text { Klađenje na virtualne } \\
\text { utrke }\end{array}$ & 0.47 & 1.098 & $Z_{\mathrm{Vu}-\mathrm{ER}}=-13.199^{* *}$ \\
\hline 4 & Elektronski rulet & 0.21 & 0.744 & \\
\hline
\end{tabular}

Legenda: $M=$ aritmetička sredina; $S D=$ standardna devijacija; $Z=$ vrijednost Wilcoxonovog testa; $S K=$ sportsko klađenje, JS=jednokratne srećke $L O=$ loto, $A U=$ igre na automatia, $V U=$ klađenje na virtualne utrke; $E R=$ elektronski rulet; ${ }^{* *} p<.001$

U tablici 5 prikazana je zastupljenost štetnih psihosocijalnih posljedica kockanja kroz tri kategorije koje se skraćeno prikazuju metaforom svjetala na semaforu čime autori ilustriraju i razinu ozbiljnosti problema: (1) zeleno svjetlo (nepostojanje problema), (2) žuto svjetlo (niska do srednja ozbiljnost štetnih psihosocijalnih posljedica) i (3) crveno svjetlo (visoka razina ozbiljnosti štetnih psihosocijalnih posljedica). Uvidom u prikazane rezultate uočavamo prilično visoku zastupljenost problema u uzorku hrvatskih srednjoškolaca. Konkretno, svega $70 \%$ srednjoškolaca nema nikakve psihosocijalne probleme povezane s kockanjem, njih 17\% ima nisko do umjereno razvijene problema, a čak $13 \%$ zadovoljava kriterije za visoku razvijenost problema povezanih s kockanjem.

Tablica 5 Deskriptivni prikaz zastupljenosti štetnih psihosocijalnih posljedica kockanja, rezultati na GPSS subskali Kanadskog upitnika kockanja adolescenata-CAGl; svi $(n=2.702)$

\begin{tabular}{|c|l|c|c|c|}
\cline { 3 - 5 } \multicolumn{2}{|c|}{} & $\begin{array}{c}\text { Zeleno } \\
\text { svjetlo }\end{array}$ & Žuto svjetlo & $\begin{array}{c}\text { Crveno } \\
\text { svjetlo }\end{array}$ \\
\hline \multirow{2}{*}{$\begin{array}{c}\text { GPSS - kategorizacija razvijenosti štetnih psihosocijalnih } \\
\text { posljedica kockanje }\end{array}$} & $\mathbf{N}^{*}$ & 1.844 & 458 & 340 \\
\cline { 2 - 6 } & $\%$ & $\mathbf{6 9 . 8}$ & $\mathbf{1 7 . 3}$ & $\mathbf{1 2 . 9}$ \\
\hline
\end{tabular}

Legenda: $N=$ apsolutni broj; *(napomena) - nedostaje odgovor za 60 sudionika; \%=relativna frekvencija/postotak

\section{Rodne razlike}

Kako bismo testirali postoje li rodne razlike u učestalosti kockanja, proveli smo MannWhitneyev U-test na svih šest vrsta igara, a rezultati testa, uz frekvencije odgovora (prevalenciju kockanja odvojeno za mladiće i djevojke) prikazane su u tablici 6. Rezultati pokazuju kako u igranju lutrijskih igara (lota i jednokratnih srećki) ne postoje rodne razlike, te možemo zaključiti da i mladići i djevojke relativno rijetko igraju ove igre.

Na svim drugim igrama na sreću utvrđeni su značajni efekti roda, na način da mladići češće igraju, pri čemu je efekt razlike ( $r)$ najviši u učestalosti sportskog klađenja $(r=.52)$. Iz rezultata možemo uočiti da se čak 36.6\% mladića redovito kladi na sportske rezultate, dok taj udio u subuzorku djevojaka iznosi $2.7 \%$. Nadalje, čak $13 . \%$ mladića redovito se kladi na virtualne utrke, njih $12.7 \%$ redovito igra igre na automatima, a $6.3 \%$ redovito igra elektronski rulet. Postoci redovitog igranja ovih igara kod djevojaka su zanemarivi u odnosu na mladiće. 
Kriminologija i socijalna integracija Vol. 24 Br. 2. 2016.

\section{Tablica 6 Rodne razlike u učestalosti kockanja srednjoškolaca - Mann-Whitneyev U test} $(n=2.702)$

\begin{tabular}{|c|c|c|c|c|c|c|c|c|c|c|c|}
\hline \multirow[b]{2}{*}{ Vrsta igre } & \multirow[b]{2}{*}{ Spol } & \multicolumn{6}{|c|}{ Učestalost kockanja (\%) } & \multicolumn{4}{|c|}{ Mann-Whitneyev U-test } \\
\hline & & Nikada & $\begin{array}{c}1 x \\
\text { godišnje } \\
\text { ili manje } \\
\text { od toga }\end{array}$ & $\begin{array}{c}1 \mathrm{x} \\
\text { mjesečno }\end{array}$ & $\begin{array}{c}1 x \\
\text { tjedno }\end{array}$ & $\begin{array}{c}\text { Nekoliko } \\
\text { puta } \\
\text { tjedno }\end{array}$ & Svakodnevno & RANG & MW U & $\mathbf{p}$ & $\mathbf{r}$ \\
\hline \multirow{2}{*}{$\begin{array}{l}\text { Sportko } \\
\text { klađenje }\end{array}$} & $\mathbf{M}$ & 34.4 & 12.3 & 16.7 & 15.3 & 12.4 & 8.9 & 1726.57 & \multirow{2}{*}{413538.0} & \multirow{2}{*}{$<.001$} & \multirow{2}{*}{.52} \\
\hline & $\check{z}$ & 83.5 & 9.8 & 3.9 & 1.5 & 0.9 & 0.3 & 987.91 & & & \\
\hline \multirow{2}{*}{ Loto } & $\mathbf{M}$ & 68.0 & 18.3 & 8.6 & 3.8 & 0.8 & 0.5 & 1343.36 & \multirow{2}{*}{901558.5} & \multirow{2}{*}{$>.050$} & \\
\hline & ž & 64.6 & 26.9 & 6.4 & 1.8 & 0.2 & 0.1 & 1359.39 & & & \\
\hline \multirow{2}{*}{$\begin{array}{l}\text { Jednokratne } \\
\text { srećke }\end{array}$} & $\mathbf{M}$ & 55.3 & 31.1 & 9.7 & 3.1 & 0.8 & 0.1 & 1339.20 & \multirow{2}{*}{896017.5} & \multirow{2}{*}{$>.050$} & \\
\hline & ž & 51.1 & 39.4 & 7.1 & 2.3 & 0.1 & I & 1363.43 & & & \\
\hline \multirow{2}{*}{$\begin{array}{l}\text { Igre na } \\
\text { automatima }\end{array}$} & M & 63.8 & 12.1 & 11.5 & 6.4 & 4.1 & 2.2 & 1523.90 & \multirow{2}{*}{683084.0} & \multirow{2}{*}{$<.001$} & \multirow{2}{*}{.28} \\
\hline & $\check{z}$ & 87.4 & 7.7 & 3.4 & 0.8 & 0.4 & 0.4 & 1184.37 & & & \\
\hline \multirow{2}{*}{$\begin{array}{l}\text { Elektronski } \\
\text { rulet }\end{array}$} & M & 82.8 & 6.2 & 4.7 & 3.5 & 1.6 & 1.2 & 1456.15 & \multirow{2}{*}{773201.5} & \multirow{2}{*}{$<.001$} & \multirow{2}{*}{.25} \\
\hline & $\check{z}$ & 98.0 & 1.1 & 0.6 & 0.1 & 0.3 & I & 1250.06 & & & \\
\hline \multirow{2}{*}{$\begin{array}{l}\text { Klađenje na } \\
\text { virtualne } \\
\text { utrke }\end{array}$} & $\mathbf{M}$ & 63.8 & 11.8 & 10.9 & 5.2 & 5.1 & 3.2 & 1565.14 & \multirow{2}{*}{628234.0} & \multirow{2}{*}{$<.001$} & \multirow{2}{*}{.37} \\
\hline & $\check{z}$ & 94.5 & 3.1 & 1.5 & 0.3 & 0.4 & 0.4 & 1144.40 & & & \\
\hline
\end{tabular}

Legenda: $M=$ =mladići; $\breve{Z}=$ djevojke; $M W U$ U=rezultati Mann-Whitneyevog testa, $p=$ =značajnost razlike; $r=$ veličina efekta; masnim (bold) slovima označene su značajne razlike

Rangiranje prosječne učestalosti kockanja odvojeno za mladiće i djevojke ponovno smo proveli Firedmanovim testom, te smo post-hoc testirali između kojih igara postoje značajne razlike kako bismo dobili konačne rangove (tablice 7 i 8). Već prvim pogledom na tablice uočavamo različitu strukturu vrste igara s obzirom na rang prosječne učestalosti. Kod mladića, koji ne samo da učestalije kockaju, vidljivo je kako su na prva dva mjesta igre s visokim adiktivnim potencijalom - sportsko klađenje, klađenje na virtualne utrke i igre na automatima. Lutrijske igre su na trećem i četvrtom mjestu, dok je na petom mjestu učestalost igranja elektronskog ruleta.

Tablica 7 Rangiranje učestalost kockanja svih igara kod mladića $(n=1.330)$

\begin{tabular}{|c|c|c|c|c|}
\hline Rang & Vrsta igre & M & SD & Pojedinačni Wilcoxonovi testovi ranga \\
\hline 1 & Sportsko klađenje & 1.86 & 1.711 & $\begin{array}{c}Z_{\text {SK-VU }}=-19.656^{* *} ; Z_{\text {SK-AU }}=-19.746^{* *} ; Z_{\text {SK-Js }}=-21.628^{* *} ; Z_{\text {SK- }} \\
L_{0}=-22.542^{* *} ; z_{\text {SK-ER }}=-23.836^{* *}\end{array}$ \\
\hline \multirow{2}{*}{2} & $\begin{array}{l}\text { Klađenje na virtualne } \\
\text { utrke }\end{array}$ & 0.85 & 1.379 & $\begin{array}{c}Z_{\text {VU-AU }}=-1.111 ; Z_{\text {VU-Js }}=-5.159^{* *} ; \\
Z_{\text {VU-LO }}=-7.984^{* *} ; Z_{\text {VU-ER }}=-12.415^{* *}\end{array}$ \\
\hline & Igre na automatima & 0.81 & 1.300 & $\begin{array}{c}Z_{\mathrm{AU}-\mathrm{ss}}=-5.203^{* *} ; Z_{\mathrm{AU}-\mathrm{LO}}=-7.356^{* *} ; \\
Z_{\mathrm{AU}-\mathrm{ER}}=-12.908^{\star *}\end{array}$ \\
\hline 3 & Jednokrante srećke & 0.63 & 0.847 & $z_{J S-L O}=-4.550^{* *} ; z_{J S-E R}=-8.515^{* *}$ \\
\hline 4 & Loto & 0.53 & 0.920 & $Z_{\text {LO-ER }}=-4.614^{* *}$ \\
\hline 5 & Elektronski rulet & 0.39 & 0.987 & \\
\hline
\end{tabular}

Legenda: $M=$ aritmetička sredina; $S D=$ standardna devijacija; $Z=$ vrijednost Wilcoxonovog testa; $S K=$ sportsko klađenje, JS=jednokratne srećke; $L O=$ loto, $A U=$ igre na automatia, $V U=$ klađenje na virtualne utrke; $E R=$ elektronski rulet; ${ }^{* *} p<.001$

Kod djevojaka (tablica 8) uočavamo u potpunosti različiti trend. One ne samo da značajno rjeđe kockaju, već su kod njih najučestalije igre sa značajno manjim adiktivnim potencijalom, one lutrijske (jednokratne srećke i loto). Sportsko klađenje, koje je kod mladića na prvom mjestu, kod djevojaka je na trećem s prosječnom vrijednošću od tek $M=0.28$. Igre na automatima zauzimaju četvrto mjesto u hijerarhiji učestalosti, a potom slijede virtualne utrke i elektronski rulet, tj. igre koje djevojke izuzetno rijetko igraju. 
Neven Ricijaš, Dora Dodig Hundrić, Aleksandra Huić, Valentina Kranželić: Kockanje mladih u Hrvatskoj...

\section{Tablica 8 Rangiranje učestalosti kockanja svih igara kod djevojaka $(n=1.372)$}

\begin{tabular}{|c|c|c|c|c|}
\hline Rang & Vrsta igre & M & SD & Pojedinačni Wilcoxonovi testovi ranga \\
\hline 1 & Jednokratne srećke & 0.61 & 0.731 & $\begin{array}{c}Z_{J S-L O}=-7.360^{* *} ; Z_{J S-S K}=-13.616^{* *} ; Z_{J S-A U}=-16.593^{* *} ; \\
Z_{J S-V U}=-20.336^{* *} ; Z_{J S-E R}=-22.620^{* *}\end{array}$ \\
\hline 2 & Loto & 0.46 & 0.726 & $\begin{array}{c}Z_{\text {LO-SK }}=-8.365^{* *} ; Z_{\text {LO-AU }}=-11.371^{* *} ; Z_{\text {LO-VU }}=-15.935^{* *} ; \\
Z_{\text {LO-ER }}=-18.550\end{array}$ \\
\hline 3 & Sportsko klađenje & 0.28 & 0.737 & $Z_{\text {SK-AU }}=-3.435^{* *} ; Z_{\text {SK-VU }}=-8.656^{* *} ; Z_{\text {SK-ER }}=-11.872^{\star *}$ \\
\hline 4 & Igre na automatima & 0.20 & 0.731 & $Z_{A U-V U}=-5.841^{* *} ; Z_{A U-E R}=-10.413^{* *}$ \\
\hline 5 & $\begin{array}{l}\text { Klađenje na virtualne } \\
\text { utrke }\end{array}$ & 0.10 & 0.504 & $Z_{\mathrm{VU}-\mathrm{ER}}=-4.484^{* *}$ \\
\hline 6 & Elektronski rulet & 0.04 & 0.294 & \\
\hline
\end{tabular}

Legenda: $M=$ aritmetička sredina; $S D=$ standardna devijacija; $Z=$ vrijednost Wilcoxonovog testa; $S K=$ sportsko klađenje, JS=jednokratne srećke; $L O=$ loto, $A U=$ igre na automatia, $V U=$ klađenje na virtualne utrke; $E R=$ elektronski rulet; ${ }^{* *} p<.001$

Na temelju prikazanih rezultata jasno je kako mladići u većoj mjeri kockaju, te se značajno učestalije uključuju u sve igre na sreću. Stoga možemo pretpostaviti da upravo oni dominanto i čine skupinu mladih s razvijenim problemima povezanim s kockanjem. Tu smo hipotezu testirali $\chi^{2}$-testom (tablica 9), te rezultati potvrđuju našu pretpostavku $\left(\chi^{2}=543.27 ; p<.001\right)$. Naime, svega oko 50\% mladića zadovoljava kriterije za "zeleno svjetlo", odnosno nema nikakve štetne psihosocijalne posljedice povezane s kockanjem. Njih oko $27 \%$ ima nisku do srednju ozbiljnost problema, a čak $23 \%$ zadovoljava kriterije za crveno svjetlo, odnosno kockanje u velikoj mjeri narušava njihovo svakodnevno psihosocijalno funkcioniranje.

Tablica 9 Rodne razlike u razvijenosti štetnih psihosocijalnih posljedica (GPSS) - $\chi^{2}$-test $(n=2.702)$

\begin{tabular}{|c|c|c|c|c|c|c|}
\hline \multicolumn{2}{|c|}{$\begin{array}{l}\text { GPSS - kategorizacija razvijenosti štetnih psihosocijalnih } \\
\text { posljedica kockanje }\end{array}$} & \multirow{2}{*}{$\begin{array}{c}\begin{array}{c}\text { Zeleno } \\
\text { svjetlo }\end{array} \\
646 \\
\end{array}$} & \multirow{2}{*}{$\begin{array}{c}\begin{array}{c}\text { Žuto } \\
\text { svjetlo }\end{array} \\
356 \\
\end{array}$} & \multirow{2}{*}{$\begin{array}{c}\begin{array}{c}\text { Crveno } \\
\text { svjetlo }\end{array} \\
312\end{array}$} & \multirow{4}{*}{$\begin{array}{c}x^{2} \\
543.27\end{array}$} & \multirow{3}{*}{$\begin{array}{c}\mathrm{p} \\
<.001\end{array}$} \\
\hline \multirow{2}{*}{ Mladići } & $\mathbf{N}$ & & & & & \\
\hline & $\%$ & 49.2 & 27.1 & 23.7 & & \\
\hline \multirow{2}{*}{ Djevojke } & $\mathbf{N}$ & 1.198 & 102 & 28 & & $<.001$ \\
\hline & $\%$ & 90.2 & 7.7 & 2.1 & & \\
\hline
\end{tabular}

Kod djevojaka je prevalencija izraženosti štetnih posljedica povezanih s kockanjem značajno različita, iako nije zanemariva. Oko $10 \%$ djevojaka nalazi se u određenom riziku - njih oko $8 \%$ zadovoljava kriterije „žutog svjetla", a oko $2 \%$ „crvenog svjetla”.

\section{Dobne razlike}

S obzirom na visoku korelaciju između razreda i dobi srednjoškolaca $(r=.894 ; p<.001)$, odnosno činjenicu da ove dvije varijable dijele gotovo $80 \%$ zajedničke varijance, dobne razlike u učestalosti kockanja testirali smo korištenjem razreda kao nezavisne varijable. Za takav smo se pristup odlučili i zbog činjenice da su određena razvojna obilježja karakteristična i za vršnjačku grupu iz aspekta razreda. Tako će primjerice svi učenici trećeg razreda biti sličniji jedni drugima, bez obzira imaju li 16 ili 17 godina, nego učenici istih godina koji pohađaju različit razred. S ciljem utvrđivanja dobnih razlika proveden je Kruskal-Wallisov test, te potom pojedinačni Mann-Whitneyevi testovi tamo gdje su značajne razlike utvrđene.

Rezultati su prikazani odvojeno za mladiće i djevojke (tablica 10). Kod djevojaka, razlike su potvrđene samo u učestalosti sportskog klađenja, na način da učenice prvog razreda srednje škole 
imaju značajno manje iskustva u klađenju u odnosu na učenice viših razreda. Kod mladića su razlike dobivene kod triju igara (sportsko klađenje, jednokratne srećke i elektronski rulet). U učestalosti igranja elektronskog ruleta efekti razlika su najveći ( $\left.K V \chi^{2}=46.64 ; p<.001\right)$, na način da maturanti značajno češće igraju ovu igru u odnosu na učenike nižih razreda. $U$ igranju jednokratnih srećki efekti razlika su značajni, ali zapravo mali, kao i kod sportskog klađenja.

Tablica 10 Razlike u učestalosti kockanja s obzirom na dob/razred, odvojeno za mladiće $(n=1.330)$ i djevojke ( $n=1.372)$ - Kruskal-Wallisov test

\begin{tabular}{|c|c|c|c|c|c|c|c|}
\hline \multicolumn{2}{|c|}{ Spol } & \multicolumn{3}{|c|}{ Mladići } & \multicolumn{3}{|c|}{ Djevojke } \\
\hline Vrsta igre & Razred & PR & $K W \chi^{2}$ & MWU & PR & $K W \chi^{2}$ & MWU \\
\hline \multirow{4}{*}{$\begin{array}{l}\text { Sportsko } \\
\text { klađenje }\end{array}$} & $1 \mathrm{r}$ & 604.41 & \multirow{4}{*}{$15.378^{*}$} & \multirow{4}{*}{$\begin{array}{c}2 r>1 r^{* *} \\
3 r, 4 r>1 r^{*}\end{array}$} & 630.24 & \multirow{4}{*}{$30.24^{* *}$} & \multirow{4}{*}{$2 r, 3 r, 4 r>1 r^{* *}$} \\
\hline & $2 r$ & 701.86 & & & 700.49 & & \\
\hline & $3 r$ & 658.30 & & & 692.49 & & \\
\hline & $4 r$ & 702.84 & & & 733.84 & & \\
\hline \multirow{4}{*}{ Loto } & $1 \mathrm{r}$ & 638.31 & \multirow{4}{*}{6.05} & & 658.76 & \multirow{4}{*}{8.684} & \\
\hline & $2 r$ & 664.19 & & & 679.39 & & \\
\hline & $3 r$ & 661.67 & & & 679.34 & & \\
\hline & $4 r$ & 703.53 & & & 734.61 & & \\
\hline \multirow{4}{*}{$\begin{array}{l}\text { Jednokratne } \\
\text { srećke }\end{array}$} & $1 \mathrm{r}$ & 666.17 & \multirow{4}{*}{$13.30^{*}$} & \multirow{4}{*}{$2 r, 4 r>3 r^{*}$} & 652.22 & \multirow{4}{*}{8.59} & \\
\hline & $2 r$ & 689.21 & & & 683.39 & & \\
\hline & $3 r$ & 613.07 & & & 683.82 & & \\
\hline & $4 r$ & 702.34 & & & 733.76 & & \\
\hline \multirow{4}{*}{$\begin{array}{l}\text { Igre na } \\
\text { automatima }\end{array}$} & $1 \mathrm{r}$ & 643.96 & \multirow{4}{*}{3.97} & & 663.62 & \multirow{4}{*}{5.45} & \\
\hline & $2 r$ & 660.16 & & & 688.76 & & \\
\hline & $3 r$ & 663.16 & & & 689.00 & & \\
\hline & $4 r$ & 698.69 & & & 702,74 & & \\
\hline \multirow{4}{*}{ Elektronski rulet } & $1 r$ & 621.82 & \multirow{4}{*}{$46.64^{\star *}$} & \multirow{4}{*}{$4 r>1 r, 2 r, 3 r^{* *}$} & 680.04 & \multirow{4}{*}{7.44} & \\
\hline & $2 r$ & 643.15 & & & 683.51 & & \\
\hline & $3 r$ & 661.75 & & & 678.22 & & \\
\hline & $4 r$ & 760.46 & & & 697.94 & & \\
\hline \multirow{4}{*}{$\begin{array}{l}\text { Klađenje na } \\
\text { virtualne utrke }\end{array}$} & $1 r$ & 649.30 & \multirow{4}{*}{2.16} & & 674.63 & \multirow{4}{*}{2.13} & \\
\hline & $2 r$ & 655.25 & & & 688.59 & & \\
\hline & $3 r$ & 682.36 & & & 686.87 & & \\
\hline & $4 r$ & 666.86 & & & 688.74 & & \\
\hline
\end{tabular}

Legenda: $P R=$ prosječni rang; $K W \chi^{2}=$ Kruskal-Wallisov hi-kvadrat; $M W U=$ Mann-Whitneyev U-test; ${ }^{*} p<.010 ;{ }^{* *} p<.001$

Logično, zanimalo nas je i postoje li razlike u izraženosti problema povezanih s kockanjem s obzirom na dob/razred što smo i provjerili $\chi^{2}$-testom (tablica 11). Rezultati su dodatno zabrinjavajući, posebno za mladiće kod kojih razlike s obzirom na razred ne postoje. Naime, u svim je razredima uočljiva vrlo visoka prevalencija štetnih psihosocijalnih posljedica povezanih s kockanjem. Između 50 i 60\% mladića, neovisno o razredu koji pohađa, osjeća neku vrstu štetnih posljedica. 
Neven Ricijaš, Dora Dodig Hundrić, Aleksandra Huić, Valentina Kranželić: Kockanje mladih u Hrvatskoj...

Tablica 11 Razlike u izraženosti štetnih psihosocijalnih posljedica kockanja (GPSS) s obzirom na dob/razred, odvojeno za mladiće $(n=1.330)$ i djevojke $(n=1.372)-\chi^{2}$-test

\begin{tabular}{|c|c|c|c|c|c|c|}
\hline \multicolumn{7}{|c|}{ GPSS kategorizacija s obzirom na razred/dob } \\
\hline & & $\begin{array}{l}\text { Zeleno } \\
\text { svjetlo }\end{array}$ & $\begin{array}{c}\text { Žuto } \\
\text { svjetlo }\end{array}$ & $\begin{array}{l}\text { Crveno } \\
\text { svjetlo }\end{array}$ & $x^{2}$ & $\mathbf{p}$ \\
\hline \multicolumn{7}{|l|}{ MLADIĆI } \\
\hline \multirow{2}{*}{ 1. razred } & $\mathbf{N}$ & 184 & 86 & 79 & \multirow{8}{*}{8.79} & \multirow{8}{*}{$>.050$} \\
\hline & $\%$ & 52.7 & 24.6 & 22.6 & & \\
\hline \multirow{2}{*}{ 2. razred } & $\mathbf{N}$ & 178 & 96 & 77 & & \\
\hline & $\%$ & 50.7 & 27.4 & 21.9 & & \\
\hline \multirow{2}{*}{ 3. razred } & $\mathbf{N}$ & 188 & 101 & 88 & & \\
\hline & $\%$ & 49.9 & 6.8 & 23.3 & & \\
\hline \multirow{2}{*}{ 4. razred } & $\mathbf{N}$ & 96 & 70 & 67 & & \\
\hline & $\%$ & 41.2 & 30.0 & 28.8 & & \\
\hline \multicolumn{7}{|c|}{ DJEVOJKE } \\
\hline \multirow{2}{*}{ 1. razred } & $\mathbf{N}$ & 369 & 19 & 8 & \multirow{8}{*}{11.89} & \multirow{8}{*}{$>.050$} \\
\hline & $\%$ & 93.2 & 4.8 & 2.0 & & \\
\hline \multirow{2}{*}{ 2. razred } & $\mathbf{N}$ & 298 & 35 & 11 & & \\
\hline & $\%$ & 86.6 & 10.2 & 3.2 & & \\
\hline \multirow{2}{*}{ 3. razred } & $\mathbf{N}$ & 287 & 27 & 5 & & \\
\hline & $\%$ & 90.0 & $8 . .5$ & 1.6 & & \\
\hline \multirow{2}{*}{ 4. razred } & $\mathbf{N}$ & 241 & 21 & 3 & & \\
\hline & $\%$ & 90.9 & 7.9 & 1.1 & & \\
\hline
\end{tabular}

Razlike s obzirom na vrstu srednjoškolskog usmjerenja

U skladu s prethodno prikazanim rezultatima, testirali smo i značajnost razlika u učestalosti kockanja, kao i izraženosti štetnih psihosocijalnih posljedica povezanih s kockanjem s obzirom na vrstu škole koju mladi pohađaju, a rezultati su prikazani u tablicama 12 i 13.

Tablica 12 Razlike u učestalosti kockanja s obzirom na vrstu škole, odvojeno za mladiće $(n=1.330)$ i djevojke ( $n=1.372)$ - Kruskal-Wallisov test

\begin{tabular}{|c|c|c|c|c|c|c|c|}
\hline \multicolumn{2}{|c|}{ Spol } & \multicolumn{3}{|c|}{ Mladići } & \multicolumn{3}{|c|}{ Djevojke } \\
\hline Vrsta igre & Vrsta škole & PR & $K W \chi^{2}$ & MWU & PR & $K W \chi^{2}$ & MWU \\
\hline \multirow{3}{*}{$\begin{array}{l}\text { Sportsko } \\
\text { klađenje }\end{array}$} & 35 & 653.67 & \multirow{3}{*}{$23.12^{* *}$} & \multirow{3}{*}{$4 S>G^{* *}$} & 654.61 & \multirow{3}{*}{5.91} & \\
\hline & $4 S$ & 717.69 & & & 683.13 & & \\
\hline & G & 599.88 & & & 700.47 & & \\
\hline \multirow{3}{*}{ Loto } & 35 & 635.44 & \multirow{3}{*}{8.88} & & 580.46 & \multirow{3}{*}{$32.44^{* *}$} & \multirow{3}{*}{$4 S, G>3 S^{* *}$} \\
\hline & $4 S$ & 694.56 & & & 692.18 & & \\
\hline & G & 652.75 & & & 721.60 & & \\
\hline \multirow{3}{*}{$\begin{array}{l}\text { Jednokratne } \\
\text { srećke }\end{array}$} & 35 & 621.54 & \multirow{3}{*}{8.88} & & 597.51 & \multirow{3}{*}{$20.10^{* *}$} & \multirow{3}{*}{$\begin{array}{l}4 S>3 S^{*} \\
G>3 S^{* *}\end{array}$} \\
\hline & $4 S$ & 682.49 & & & 691.68 & & \\
\hline & G & 684.77 & & & 715.68 & & \\
\hline \multirow{3}{*}{$\begin{array}{l}\text { Igre na } \\
\text { automatima }\end{array}$} & 35 & 687.93 & \multirow{3}{*}{29.21 ** } & \multirow{3}{*}{$3 S, 4 S>G * *$} & 664.34 & \multirow{3}{*}{2.859} & \\
\hline & $4 S$ & 701.83 & & & 690.12 & & \\
\hline & G & 588.76 & & & 692.20 & & \\
\hline \multirow{3}{*}{ Elektronski rulet } & 35 & 647.72 & \multirow{3}{*}{$13.95^{*}$} & \multirow{3}{*}{$3 S, 4 S>G^{*}$} & 683.64 & \multirow{3}{*}{0.60} & \\
\hline & 45 & 695.35 & & & 689.19 & & \\
\hline & G & 639.13 & & & 685.74 & & \\
\hline
\end{tabular}




\begin{tabular}{|c|c|c|c|c|c|c|}
\hline \multirow{3}{*}{$\begin{array}{l}\text { Klađenje na } \\
\text { virtualne utrke }\end{array}$} & $3 S$ & 683.87 & \multirow{3}{*}{$22.23^{* *}$} & \multirow{3}{*}{$3 S, 4 S>G * *$} & 684.92 & \multirow{3}{*}{0.25} \\
\hline & $4 S$ & 697.88 & & & 689.53 & \\
\hline & G & 598.75 & & & 685.05 & \\
\hline
\end{tabular}

Legenda: $3 S$ = strukovna trogodišnja (obrtnička) škola; $4 S=$ strukovna četverogodišnja škola; $G=$ gimnazija; $P R=$ prosječni rang; $K W \chi^{2}=$ Kruskal-Wallisov hi-kvadrat; MWU = Mann-Whitneyev U-test; ${ }^{*} p<010 ;{ }^{* *} p<001$

Već prvim pogledam na tablicu 12 uočavamo različitu sliku između mladića i djevojaka. Kod djevojaka razlike postoje samo u lutrijskim igrama na način da učenice strukovnih trogodišnjih srednjih škola imaju značajno manje iskustva s igranjem lota i jednokratnih srećki u odnosu na učenice gimnazija i strukovnih četverogodišnjih programa. Kod mladića, razlike su značajne na svim visoko rizičnim igrama na način da učenici gimnazijskog programa nešto rjeđe kockaju, a efekti razlika najveći su u igranju igara na automatima $\left(K V \chi^{2}=29.21 ; p<.001\right)$.

Tablica 13 Razlike u izraženosti štetnih psihosocijalnih posljedica kockanja (GPSS) s obzirom na vrstu škole, odvojeno za mladiće $(n=1.330)$ i djevojke $(n=1.372)-\chi^{2}$-test

\begin{tabular}{|c|c|c|c|c|c|c|}
\hline \multicolumn{7}{|c|}{ GPSS s obzirom na vrstu škole } \\
\hline & & $\begin{array}{l}\text { Zeleno } \\
\text { svjetlo }\end{array}$ & $\begin{array}{c}\text { Žuto } \\
\text { svjetlo }\end{array}$ & $\begin{array}{l}\text { Crveno } \\
\text { svjetlo }\end{array}$ & $x^{2}$ & $\mathbf{p}$ \\
\hline \multicolumn{7}{|l|}{ MLADIĆI } \\
\hline \multirow{2}{*}{ Strukovna trogodišnja škola } & $\mathbf{N}$ & 181 & 107 & 90 & \multirow{6}{*}{19.06} & \multirow{6}{*}{$<.010$} \\
\hline & $\%$ & 47.9 & 28.3 & 23.8 & & \\
\hline \multirow{2}{*}{ Strukovna četverogodišnja škola } & $\mathbf{N}$ & 249 & 159 & 155 & & \\
\hline & $\%$ & 44.2 & 28.2 & 27.5 & & \\
\hline \multirow{2}{*}{ Gimnazija } & $\mathbf{N}$ & 216 & 90 & 67 & & \\
\hline & $\%$ & 57.9 & 24.1 & 18.0 & & \\
\hline \multicolumn{7}{|l|}{ DJEVOJKE } \\
\hline \multirow{2}{*}{ Strukovna trogodišnja škola } & $\mathbf{N}$ & 221 & 18 & 8 & \multirow{6}{*}{2.94} & \multirow{6}{*}{$>.050$} \\
\hline & $\%$ & 89.5 & 7.3 & 3.2 & & \\
\hline \multirow{2}{*}{ Strukovna četverogodišnja škola } & $\mathbf{N}$ & 382 & 37 & 9 & & \\
\hline & $\%$ & 89.3 & 8.6 & 2.1 & & \\
\hline \multirow{2}{*}{ Gimnazija } & $\mathbf{N}$ & 595 & 47 & 11 & & \\
\hline & $\%$ & 91.1 & 7.2 & 1.1 & & \\
\hline
\end{tabular}

Kod djevojaka, razlike u zastupljenosti štetnih psihosocijalnih posljedica (tablica 13) ne postoje, dok su mladići strukovnih škola u nešto većoj mjeri razvili štetne posljedice povezane $s$ kockanjem (23-28\%) u odnosu na gimnazijalce (18\%), iako efekti razlika nisu veliki $\left(\chi^{2}=19.06 ; p<.010\right)$. Pritom i dalje valja naglasiti kako je prevalencija štetnih posljedica kod mladića izuzetno značajna, neovisno o razredu ili vrsti škole koju pohađaju.

\section{Rasprava}

Iz prikazanih je rezultata vidljivo da je kockanje, iako formalno-pravno namijenjeno isključivo odraslim osobama, aktivnost u koju se mladi na našim prostorima u velikoj mjeri uključuju. Naime, njih čak $72.9 \%$ kockalo je barem jednom u životu neku formalno priređivanu igru, što nam govori u prilog značajnoj dostupnosti, ali i pristupačnosti igara na sreću. Kada govorimo o mladima, posebno nam je važan element pristupačnosti koji se razlikuje od dostupnosti. Točnije, kockanje može biti u našem društvu dostupno (postoje mjesta na kojima se priređuju igre na sreću), ali mladi, kako 
je Zakonom i predviđeno, ne bi smjeli imati pristupa takvim aktivnostima. To nije slučaj, te je za pretpostaviti da se zakonska regulativa nedovoljno poštuje.

No, kako bismo dobili cjelovitu sliku o navikama kockanja mladih, od posebne nam je važnosti informacija u koje se igre na sreću uključuju. Rezultati su pokazali da najveći udio mladih ima iskustvo sudjelovanja u lutrijskim igrama i sportskom klađenju. Ovakve smo rezultate i očekivali: lutrijske se igre zbog svojih obilježja vrlo često smatraju bezazlenima i istraživanja kontinuirano potvrđuju njihovu značajnu zastupljenost u različitim dobnim skupinama (Glavak Tkalić i Miletić, 2012), a sportsko klađenje je igra na sreću koja je u našem društvu izuzetno zastupljena i koja je (zbog svoje neizostavne povezanosti sa sportskim događajima), mladima posebno privlačna i zanimljiva. Uz to, sportsko klađenje je i najučestalija igra na sreću, te se redovito (jednom tjedno ili češće) na sportske rezultate kladi čak $20 \%$ srednjoškolaca. Nažalost, iz praktičnog iskustva znamo kako je i kod ove igre na sreću često prisutno podcjenjivanje njene rizičnosti. Točnije, često se doživljava kao bezazlena, nerijetko se niti ne smatra kockanjem, a istraživanja govore suprotno. Tako je i među hrvatskim srednjoškolcima utvrđeno da skupinu mladih s izraženim problemima u velikoj mjeri čine upravo oni koji se redovito klade, te da je kockanje povezano i s manifestiranjem drugih rizičnih ponašanja (Dodig, 2013; Ricijaš, Dodig Hundrić i Kranželić, 2015).

Iskustvo kockanja na automatima ima oko $20 \%$ srednjoškolaca, a elektronski rulet iskusilo je njih oko $10 \%$. Ove su igre na sreću značajno manje zastupljene u odnosu na sportsko klađenje i mladi ih igraju relativno rijetko. No, i takvi su pokazatelji alarmantni s obzirom da je riječ o mladoj populaciji i o aktivnostima s vrlo visokim tzv. adiktivnim potencijalom. Naime, Griffiths (1999) navodi da su, zbog velike frekvencije događaja, kratkih intervala između uloga $\mathrm{i}$ isplate, iskustva skorog dobitka, te mogućnosti osvajanja vrlo visokog iznosa uz minimalan ulog, ove igre posebno rizične za razvoj problema. Također, ne smijemo smetnuti s uma niti činjenicu da se ove igre na sreću priređuju u automat klubovima i/ili kasinima, te da informacija o tome da mladi imaju iskustvo kockanja na takvim mjestima sugerira da na tržištu igara na sreću postoji ozbiljan problem kršenja zakonske regulative. Nadalje, riječ je o mjestima koja su rizična i za uključivanje mladih u druga neprihvatljiva ponašanja, poput konzumacije sredstava ovisnosti i delinkventnog ponašanja.

Ovakvi rezultati još jednom potvrđuju da se kockanje adolescenata, kao i mnoga druga ponašanja tijekom adolescencije, javlja na kontinuumu učestalosti, od potpune neuključenosti, preko eksperimentiranja i povremenog kockanja, do onog redovitog. Krajnost na takvom kontinuumu vrlo često dovodi i do ozbiljnih posljedica, te značajnih problema u psihosocijalnom funkcioniranju. I dok se, kao što je u uvodu ovog rada detaljno prikazano, prevalencija problematičnog kockanja mladih u različitim zemljama Europe kreće između 1 i $8 \%$, ovim je istraživanjem utvrđen udio od čak $12.9 \%$ mladih koji osjećaju ozbiljne štetne psihosocijalne posljedice kockanja. Dobivene je rezultate teško neposredno uspoređivati s drugim studijama s obzirom da je korišten relativno novi instrument procjene, koji se tek sada, recentnim istraživanjima sve više koristi u svijetu. Međutim, dostupni rezultati istraživanja koji su koristili CAGI na uzorku kanadskih srednjoškolaca govore o $1.3 \%$ mladih ( $n=2.374$ od 12 do 18 godina) koji su razvili ozbiljne probleme povezane s kockanjem, odnosno o značajno manjem udjelu. Za pretpostaviti je da ovako velike razlike možemo pripisati metodološkim specifičnostima ovih istraživanja prvenstveno povezanih s razlikama u reprezentativnosti i dobnom rasponu uzorka, no trend daleko veće zastupljenosti problema u našoj zemlji nedvojben je. U tom kontekstu svakako u obzir treba uzeti i okolinske čimbenike. Prije svega se to 
odnosi na već spomenutu dostupnost i nepridržavanje zakonske regulative, ali i oglašavanje te opću prihvaćenost kockanja (s posebnim naglaskom na sportsko klađenje). U prilog ovakvoj interpretaciji rezultata, govore i podaci prikupljeni u susjednoj Bosni i Hercegovini, zemlji sa sličnom regulativom kockanja, te izraženom dostupnošću igara na sreću, a na temelju metodologije istovjetne onoj korištenoj u našem istraživanju. Naime, tamo je, u uzorku Sarajevskih i Tuzlanskih srednjoškolaca, također utvrđen značajan udio (oko 8\%) mladih s problemima povezanim s kockanjem (Bijedić, Kuralić-Čišić, Kovačević i Vardo, 2015).

Usmjerimo li se samo na subuzorak mladića, rezultati su dodatno alarmantni. Naime, istraživanjem je utvrđeno da mladići kockaju intenzivnije od djevojaka, te da su njihove kockarske preferencije značajno različite. Konkretno, mladićima je na prvom mjestu sportsko klađenje (s prosječnom vrijednošću $M=1.86$ ), dok ono kod djevojaka zauzima tek treće mjesto i ima nisku prosječnu vrijednost $(M=0.28)$. Djevojkama su, pak, na prva dva mjesta lutrijske igre koje su manje podložne za razvoj problema. Primjerice, istraživanjem Sprostonove, Erensa i Orforda (2000) utvrđeno je da prevalencija problematičnog kockanja kod osoba koje su isključivo igrale lutrijske igre iznosi tek $0.1 \%$. Naravno, rizik tih aktivnosti ne smijemo zanemariti kada je riječ o mladoj populaciji, no on je neusporediv s onim koji nose sportsko klađenje i/ili igre na automatima. Očekivano, mladići u značajno većoj mjeri čine skupinu s razvijenim problemima: udio djevojaka koje zadovoljavaju kriterije za tzv. crveno svjetlo je $2.1 \%$, a mladića čak $23.7 \%$. Uz to, njih oko $27 \%$ manifestira srednju razinu problema povezanih s kockanjem (žuto svjetlo), te se tako udio mladića kojima kockanje u umjerenoj ili velikoj mjeri narušava psihosocijalno funkcioniranje penje na čak $50 \%$. Nalazi o rodnim razlikama u skladu su s mnogobrojnim inozemnim istraživanjima koja, gotovo bez iznimke, potvrđuju takav trend (National Research Council, 1999; Desai, Maciejewski, Pantalon i Potenza, 2005; Stuhldreher, Stuhldreher i Forrest, 2007; Shead, Derevensky i Gupta, 2010). Povežemo li ove rezultate s onima na cjelokupnom uzorku, jasno je da sličnosti s drugim zemljama nakon toga prestaju. Točnije, kod nas je udio mladih, posebno mladića, kojima ova rizična aktivnost ometa osobno, obiteljsko, školsko i akademsko funkcioniranje, višestruko veći.

Poznato je da se učenici, kada je riječ o uključivanju u različita rizična ponašanja, često razlikuju s obzirom na vrstu škole koju pohađaju (više u Ricijaš, Dodig Hundrić i Kranželić, 2015). Tako skupinu visokorizičnih mladih čine upravo oni koji imaju poteškoće sa školovanjem (Ajduković, Ručević i Šincek, 2009), a učenici strukovnih škola u većoj mjeri konzumiraju alkohol i cigarete (Kuzman, 2003). Stoga smo i u ovom istraživanju očekivali da će kockanje biti manje prevalentno među gimnazijalcima, što se i potvrdilo, iako su efekti tih razlika manji od očekivanih. Kada je riječ o mladićima, učenici trogodišnjih strukovnih škola nešto više sudjeluju u igrama s visokim adiktivnim potencijalom, te među njima ima nešto više onih s razvijenim problemima. No, kako su efekti tih razlika relativno niski, općenito možemo zaključiti da mladići u velikoj mjeri učestalo kockaju, neovisno o vrsti škole koju pohađaju.

Slično je i s razlikama s obzirom na dob/razred, što posebno brine. Pretpostavili smo kako će mlađi učenici kockati rjeđe, te imati manje razvijene negativne psihosocijalne posljedice zbog svojeg kockanja. Međutim, nismo utvrdili velike razlike s obzirom na učestalost kockanja učenika u različitim razredima, a zastupljenost problematičnog kockanja podjednaka je u svim dobnim skupinama tj. razredima. Ovakvi nalazi nameću zaključak da srednjoškolci (mahom mladići) počinju kockati i prije srednjoškolskog obrazovanja, da to čine intenzivno te da njihovo kockanje vrlo brzo 
iz društvenog prelazi u rizično/problematično. Ovakvi nalazi posebno su zabrinjavajući s obzirom na to da je utvrđeno da je rani početak kockanja snažan rizičan čimbenik za nastavak kockanja u odrasloj dobi, te razvoj ovisnosti o kockanju. Osim toga, naši nalazi pokazuju kako bi buduća longitudinalna istraživanja trebala uzeti u obzir manji raspon godina, te ispitati i problematično kockanje adolescenata, s obzirom na to da visok postotak mladih u našem uzorku već ima ozbiljne psihosocijalne posljedice zbog svojeg kockanja. Nepostojanje značajnijih dobnih razlika također govori u prilog značajnom utjecaju okolinskih čimbenika i društvene klime u kojoj mladi odrastaju, a koja snažno doprinosi uključivanju u igre na sreću i razvoju problematičnog kockanja, neovisno o akademskom uspjehu, potencijalnom profesionalnom usmjerenju, pa čak i stadiju adolescencije.

U ovom radu, po prvi smo puta u našoj zemlji sustavno ispitali zastupljenost kockanja i problema povezanih s kockanjem mladih kako iz regionalnih urbanih središta, tako i iz manjih gradova. Unatoč tome što uzorak u ovom istraživanju nije reprezentativan za cijelu populaciju srednjoškolaca u Hrvatskoj, što nedvojbeno predstavlja jedan od nedostataka ovog istraživanja, prilikom osmišljavanja uzorka u pojedinom gradu dodatnu pozornost smo posvetili tome da uzorak srednjoškolaca bude reprezentativan barem za uključene gradove. Buduća istraživanja trebala bi se temeljiti baš na nacionalno reprezentativnom uzorku, ili barem uključiti i srednjoškolce iz manjih gradova i iz ostalih dijelova Hrvatske. Međutim, s obzirom na to da se podaci o visokoj uključenosti srednjoškolaca u kockarske aktivnosti dobiveni u ovom istraživanju poklapaju s nalazima drugih istraživanja provedenih u Hrvatskoj (Glavak Tkalić i Miletić, 2012; Koić i Medved, 2009; Puharić, Kudumija Sljepčević, Badrov i Petričević, 2016), te da su adolescenti iz manjih mjesta i sela obuhvaćeni u srednjim školama koje uglavnom i postoje samo u većim mjestima i gradovima, smatramo da podaci prikupljeni na nacionalno reprezentativnom uzorku ne bi u većoj mjeri odstupali od podataka prikazanih u ovom radu.

Dobiveni nalazi o rodnim, dobnim te razlikama u vrstama školskog usmjerenja nadalje proširuju kako domaće, tako i međunarodne spoznaje o rizičnim čimbenicima za razvoj problematičnog kockanja, te za veće uključivanje u kockanje i klađenje mladih. Osim ovih spoznaja, drugi do sada objavljeni hrvatski znanstveni radovi usmjeravali su se specifično na doprinos različitih obilježja ličnosti, razmišljanja i ponašanja u objašnjenju razvoja problema povezanih s kockanjem kao i stjecanjem uvida u korelate problematičnog kockanja mladih (Dodig, 2013; Ricijaš, Dodig Hundrić i Kranželić, 2015; Ricijaš, Dodig Hundrić i Huić, 2016). Buduća istraživanja trebala bi uključiti i širi društveni kontekst mladih te ispitati i učitelje i roditelje adolescenata te njihovu ulogu u podržavanju i održavanju kockanja mladih, što je tema koja je podzastupljena kako i u domaćim tako i u stranim istraživanjima.

\section{Zaključak}

Nalazi o raširenosti kockanja, posebno sportskog klađenja, među mahom maloljetnim mladićima su alarmantni, te potvrđuju teorijske pretpostavke o povezanosti dostupnosti i liberalnog tržišta s većom incidencijom kockanja te višim stopama problematičnog kockanja. Osim toga, naši rezultati pružaju temelj za razvoj kvalitetnih socijalnih politika, javnozdravstvenih strategija, te intervencija usmjerenih prema djeci i mladima, kao i za buduća znanstvena istraživanja. Spoznaje o rodnim, dobnim te razlikama u vrstama školskog usmjerenja, koje su također proizašle iz ove 
studije, pokazuju kako štetne psihosocijalne posljedice kockanja pogađaju uglavnom mladiće, neovisno o školskom uspjehu, srednjoškolskom usmjerenju ili razvojnoj dobi, te značajno doprinose domaćem, ali i međunarodnom korpusu znanja o području.

Nedvojbeno je da Republika Hrvatska treba slijediti primjer brojnih europskih zemalja koje pokušavaju adekvatno odgovoriti na ovaj rastući problem. No, ono što nas razlikuje od većine zemalja jest snažna izraženost problema, koju ju je izuzetno važno osvijestiti na različitim razinama. Naime, problematično kockanje ometa obiteljsko, školsko, osobno i socijalno funkcioniranje mlade osobe tj. otežava postizanje očekivanih razvojnih ishoda što dugoročno, uz ozbiljne osobne i obiteljske posljedice, predstavlja trošak i za samu državu. Drugim riječima, stručni i znanstveni napori profesionalaca koji rade $s$ djecom i mladima biti će vrlo ograničenog učinka ne počne li društvo percipirati kockanje mladih kao ozbiljno rizično ponašanje, te ako tržište igara na sreću nije dovoljno dobro regulirano. Izazov koji naše društvo treba prihvatiti jest usklađivanje brige za djecu i mlade, kao i druge vulnerabilne skupine, s jedne strane, s financijskim interesima države i priređivača s druge strane.

\section{Literatura}

Ajduković, M., Kolesarić, V. (Ur.) (2003): Etički kodeks istraživanja s djecom. Zagreb: Državni zavod za zaštitu obitelji, materinstva i mladeži.

Ajduković, M., Ručević, S., Šincek, D. (2009): Istraživanje rasprostranjenosti rizičnog i delinkventnog ponašanja djece i mladih u urbanim sredinama - dodatni poticaj za ciljanu prevenciju. Dijete i društvo. 10 (1/2). 27-47.

Becoña, E., Míguez, M. C., Vázquez, F. (2001): El juego problema en los estudiantes de Enseñanza Secundaria. Psicothema. 13. 551-556.

Bijedić, M., Kuralić-Čišić, L., Kovačević, R., Vardo, E. (2015): Obilježja kockanja srednjoškolaca u Sarajevu i Tuzli - izvještaj o rezultatima istraživanja, Edukacijsko-rehabilitacijski fakultet Sveučilišta u Tuzli, Tuzla.

Blaszczynski, A., Nower, L. (2002): A pathways model of problem and pathological gambling. Addiction. 97 (5). 487-499.

Calado, F., Alexandre, J., Griffiths, M.D. (2016): Prevalence of Adolescent Problem Gambling: A systematic Review of Recent Research. Journal of Gambling Studies. doi:10.1007/ s10899-016-9627-5

Campell, F., Lester, D. (1999): The Impact of gambling opportunities on compulsive gambling. Journal of Social Psychology. 139 (1). 126-127.

Carbonneau, R., Vitaro, F., Brendgen, M., Tremblay, R. E. (2015): Variety of gambling activities from adolescence to age 30 and association with gambling problems: a 15-year longitudinal study of a general population sample. Addiction. 110 (12). 1985-1993.

Castren, S., Grainger, M., Lahti, T., Alho, H., Salonen, A.H. (2015): At-risk and problem gambling among adolescence: a convenience sample of first-year junior high school students in Finland. Substance Abuse Treatment, Prevention and Policy. 10, 9. DOI 10.1186/ s13011-015-0003-8

Colasante, E., Gori, M., Bastiani, L., Scalese, M., Siciliano, V., Molinaro, S. (2014): Italian Adolescent Gambling Behavior: Psychometric Evaluation of south Oaks Gambling Screen: 
Revised for Adolescents (SOGS-RA) among a sample of Italian students. Journal of Gambling Studies. 30 (4). 789-801.

Delfabbro, P., King, D., Griffiths, M. D. (2014): From adolescent to adult gambling: An analysis of longitudinal gambling patterns in South Australia. Journal of Gambling Studies. 30 (3). 547-563.

Derevensky, J., Gilbeau, L. (2015): Adolescent gambling: Twenty-five years of research. Canadian Journal of Addiction/Le Journal Canadien d'Addiction. 6. 4-12.

Derevensky, J.L., Gupta, R. (2000): Prevalence estimates of adolescent gambling: A comparison of the SOGS-RA, DSM-IV-J, and the GA. 20 Questions. Journal of Gambling Studies. 16. $227-251$.

Desai, R.A., Maciejewski, P.K., Pantalon, M.V., Potenza, M.N. (2005): Gender differences in adolescent gambling. Annals of Clinical Psychiatry. 17 (4). 249-258.

Dijagnostički i statistički priručnik za duševne poremećaje: DSM-IV- međunarodna verzija s MKB šiframa (1996): Jastrebarsko: Naklada Slap.

Dodig, D. (2013): Assessment challenges and determinants of adolescents' adverse psychosocial consequences of gambling. Kriminologija i socijalna integracija. 21 (2). 15-29.

Dodig, D., Ricijaš, N. (2011): Obilježja kockanja zagrebačkih adolescenata. Ljetopis socijalnog rada. 18 (1). 103-125.

Donati, M. A., Chiesi, F., Primi, C. (2013): A model to explain at-risk/problem gambling among male and female adolescents: gender similarities and differences. Journal of Adolescence. 36 (1). 129-137.

Felsher, J.R., Derevensky, J.L., Gupta, R. (2004): Lottery Playing Amongst Youth: Implications for Prevention and Social Policy. Journal of Gambling Studies. 20 (2). 127-153.

Ferris, J., Wynne, H. (2001): The Canadian problem gambling index: Final report. Submitted for the Canadian Centre on Substance Abuse. https://www.problemgambling.ca/EN/ Documents/Problem GamblingSeverityIndex.pdf (Pristupljeno: 15.5.2016.)

Fisher, S. (2000): Developing the DSM-IV-DSM-IV Criteria to Identify Adolescent Problem Gambling in Non-Clinical Populations. Journal of Gambling Studies. 16 (2). 253-273.

Fisher, S. (1993): Gambling and pathological gambling in adolescents. Journal of Gambling Studies. 9 (3). $277-288$.

Glavak Tkalić, R., Miletić, G.M. (2012): Igranje igara na sreću u općoj populaciji Republike Hrvatske: Istraživačko izvješće. Zagreb: Institut društvenih znanosti Ivo Pilar.

Griffiths, M. D. (1999): The psychology of the near miss (revisited). British Journal of Psychology. 90. 441-445.

Griffiths, M.D. (2005): Does advertising of gambling increase gambling addiction? International Journal of Mental Health and Addiction. 3 (2). 15-25.

Griffiths, M. D., Wood, R. T. A. (2007): Adolescent Internet gambling: Preliminary results of a national survey. Education and Health. 25. 23-27.

Gupta, R., Derevensky, J.L. (1998): Adolescent gambling behavior: A prevalence study and examination of the correlates associated with excessive gambling. Journal of Gambling Studies. 14. 319-345. 
Hanss, D., Mentzoni, R. A., Blaszczynski, A., Molde, H., Torsheim, T., Pallesen, S. (2014): Prevalence and correlates of problem gambling in a representative sample of Norwegian 17-year-olds. Journal of Gambling Studies, http://link.springer.com/article/10.1007/ s10899-014-9455-4/fulltext.html (Pristupljeno: 7.7.2016.)

Huang, J. H., Boyer, R. (2007): Epidemiology of youth gambling problems in Canada: A national prevalence study. Canadian Journal of Psychiatry. 52. 657-665.

Jacobs, D.F. (2000): Juvenile gambling in North America: An analysis of long term trends and future prospects. Journal of Gambling Studies. 16 (2/3). 119-152.

Johansson, A., Götestam, K. G. (2003): Gambling and problematic gambling with money among Norwegian youth (12-18 years). Nordic Journal of Psychiatry. 57. 317-321.

Koić, E., Medved, B. (2009): Stavovi mladih o kockanju. Hrvatski časopis za javno zdravstvo. 5 (17).

Kristiansen, S. G., Jensen, S. M. (2014): Prevalence and correlates of problematic gambling among Danish adolescents. International Journal of Social Welfare. 23. 89-99.

Kuzman, M. (2003): Ovisnička ponašanja u učenika u Hrvatskoj i Europi. Paediatria Croatica. 47 (1). 173-184.

Ladouceur, R., Jacques, C., Ferland, F., Giroux, I. (1999): Prevalence of problem gambling: a replication study 7 years later. Canadian Journal of Psychiatry. 44 (8). 802-804.

Lesieur, H.R., Blume, S.B. (1987): The South Oaks Gambling Screen (SOGS): a new instrument for the identification of pathological gamblers. The American Journal of Psychiatry, 144 (9). 1184-1192.

Lupu, V., Onaca, E., Lupu, D. (2002): The prevalence of pathological gambling in Romanian teenagers. Minerva Medica. 93. 413-418.

Lupu, V., Todirita, I. R. (2013): Updates of the prevalence of problem gambling in Romanian teenagers. Journal of Gambling Studies. 29. 29-36.

Molinaro, S., Canale, N., Vieno, A., Lenzi, M., Siciliano, V., Gori, M. et al. (2014): Country and individual-level determinants of probable problematic gambling in adolescence: $\mathrm{A}$ multi-level cross-national comparison. Addiction. 109. 2089-2097.

Mravčík, V., Černý, J., Leštinová, Z., Chomynová, P., Grohmannová, K., Licehammerová, Š., Ziegler, A., Kocarevová, V. (2014): Gambling in the Czech Republic, Its Correlates and Consequences. Mravčík, V. (Ur.). Prag: Úřad vlády České republiky. http://www. drogy-info.cz/data/obj_files/1619/706/GAMBLING\%20REPORT_2013_EN_fin_web_fin. pdf (Pristupljeno: 14.7.2016.)

National Research Council (1999): Pathological Gambling: A critical review. Washington, DC: National Academy Press.

Nower, L., Blaszczynski, A. (2004): A Pathways Approach to Treating Youth Gamblers. U: Gupta, R., Derevensky, J.D. (ur.): Gambling Problems in Youth - Theoretical and Applied Perspectives. New York: Kluwer Academic/Plenum Publishers. 284-303.

Olasson, D. T., Sigurdardottir, K. J., Smari, J. (2006): Prevalence estimates of gambling participation and problem gambling among 16-18-year-old students in Iceland: A comparison of the SOGS-RA and DSM-IV-MR-J. Journal of Gambling Studies. 22. 23-39. 
Neven Ricijaš, Dora Dodig Hundrić, Aleksandra Huić, Valentina Kranželić: Kockanje mladih u Hrvatskoj...

Productivity Commission (1999): Australia's Gambling Industries Inquiry Report. Australia's Government Productivity Commission. http://www.pc.gov.au/inquiries/completed/ gambling/report (Pristupljeno: 5.6.2016.)

Puharić, Z., Kudumija Sljepčević, M., Badrov, T., Petričević, N. (2016): Gambling among Teenagers in Bjelovar-Bilogora County (Croatia). Alcoholism and Psychiatry Research. 52. 5-16.

Rahman, A. S., Pilver, C. E., Desai, R. A., Steinberg, M. A., Rugle, L., Krishnan-Sarin, S., Potenza, M. N. (2012): The relationship between age of gambling onset and adolescent problematic gambling severity. Journal of psychiatric research. 46 (5). 675-683.

Raylu, N. i Oei, T.P. (2002): Pathological gambling. A comprehensive review. Clinical Psychology Review. 22 (7). 1009-1070.

Ricijaš, N., Dodig, D., Huić, A., Kranželić, V. (2011): Navike i obilježja kockanja adolescenata u urbanim sredinama - izvještaj o rezultatima istraživanja. https://bib.irb. hr/prikazirad?\&rad=654654 (Pristupljeno, 15.4.2016.)

Ricijaš, N., Dodig Hundrić, D., Huić, A. (2016). Predictors of adverse gambling related consequences among adolescent boys. Children and youth services review. 67. 168174.

Ricijaš, N., Dodig Hundrić, D., Kranželić, V. (2015): Sportsko klađenje i druga rizična ponašanja hrvatskih srednjoškolaca. Hrvatska revija za rehabilitacijska istraživanja. 15 (2) 41-56.

Rossow, I., Molde, H. (2006): Chasing the criteria: Comparing SOGS-RA and the Lie/Bet screen to assess prevalence of problem gambling and 'at-risk' gambling among adolescents. Journal of Gambling Issues. 18. 57-71.

Shaffer, H.J., Hall, M.M. (1996): Estimating the prevalence of adolescent gambling disorders: A quantitative synthesis and guide toward standard gambling nomenclature. Journal of Gambling Studies. 12 (2). 193-214.

Shaffer, H.J., LaBrie, R., Scanlan, K.M., Cummings, T.N. (1994): Pathological gambling among adolescents: Massachusetts gambling screen. Journal of Gambling Studies. 10 (4). 339-362.

Shead, N. W., Derevensky, J. L., Gupta, R. (2010): Risk and protective factors associated with youth problem gambling. International Journal of Adolescent Medicine and Health. 22 (1). 39-58.

Skokauskas, N. (2009): Lithuania. U: Meyer G., Hayer T., Griffiths MD. (ur.). Problem Gaming in Europe: Challenges, prevention, and interventions. New York, NY: Springer. 173-188.

Sproston, K., Erens, B., Orford, J. (2000): Gambling Behaviour in Britain: Results from the British Gambling Prevalence Survey http://www.gamblingcommission.gov.uk/pdf/ Gambling\%20behaviour\%20in\%20Britian\%20results\%20from\%20the\%20BGPS\%20 2000\%20-\%20Jun\%202007.pdf (Pristupljeno: 15.7.2016.)

Steinberg, L. (2007): Risk Taking in Adolescence: New Perspectives from Brain and Behavioral Science. Current Directions in Psychological Science. 16 (2). 55-59.

Steinberg, L. (2008): A social neuroscience perspective on adolescent risk taking. Development Review. 28 (1). 78-106.

Steinberg, L. (2010): A Dual System Model of Adolescent Risk-Taking. Developmental Psychobiology. 52 (3). 216-224. 
Stuhldreher, W.L., Stuhldreher, T.J., Forrest, K.Y-Z. (2007): Gambling as an emerging Health Problem on Campus. Journal of American College Health. 56 (1). 75-83.

Tozzi, L., Akre, C., Fleury-Schubert, A., Suris, J. (2013): Gambling among youths in Switzerland and its association with other addictive behaviours: A population-based study. Swiss Medical Weekly; 143:w13768. http://www.smw.ch/content/smw-2013-13768/ (Pristupljeno: 12.7.2016.)

Tremblay, J., Stinchfield, R., Wiebe, J., Wynne, H. (2010): Canadian Adolescent Gambling Inventory (CAGI) Phase III Final Report. Submitted to the Canadian Centre on Substance Abuse and the Interprovincial Consortium on Gambling Research.

Villella, C., Martinotti, G., Di Nicola, M., Cassano, M., La Torre, G., Gliubizzi, M.D., Messeri, I., Petruccelli, F., Bria, P., Janiri, L., Conte, G. (2011): Behavioural addictions in adolescents and young adults: results from prevalence study. Journal of Gambling Studies. 27 (2). 203-214.

Volberg, R.A., Gupta, R., Griffiths, M.D., Olason, D.T., Delfabbro, P. (2010): An international perspective on youth gambling prevalence studies. International Journal of Adolescent Medicine and Health. 22 (1). 3-38.

Welte, J. W., Barnes, G. M., Tidwell, M. C. O., Hoffman, J. H. (2008): The prevalence of problem gambling among US adolescents and young adults: Results from a national survey. Journal of Gambling Studies. 24. 119-133.

Welte, J.W., Barnes, G.M., Tidwell, M.O., Hoffman, J.H. (2009): Legal Gambling Availability and Problem Gambling Among Adolescents and Young Adults. International Journal of Gambling Studies. 9 (2). 89-99.

Winters, K.C., Stinchfield, R., Fulkerson, J. (1993): Patterns and characteristics of adolescent gambling. Journal of Gambling Studies. 9. 371-386.

Zakon o elektroničkim medijima, Narodne Novine 153/09, 84/11, 94/13, 136/13.

Zakon o igrama na sreću, Narodne Novine 87/09, 35/13, 158/13, 41/14, 143/14. 